\title{
العلاقة بين استراتيبيات التعلّم والدافعية للتعلم لدى طلبة كلية التربية الثالثة بجامعة البعث
}

قسم الإرشاد النفسبي

\section{كلية التربية ـ جامعة البـعث}

د. أحمد حاة موستى

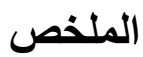

هدف البحث الحالي إلى التعرف على العلاقة الارتباطية بين استر اتيجيات التعلم و الدافعية للتعلم

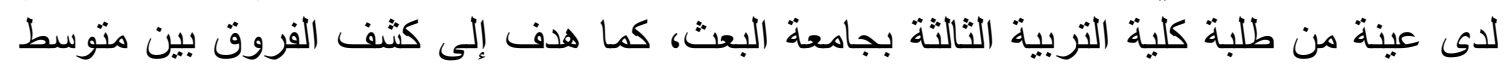

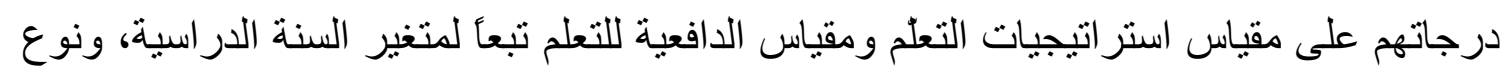
الثهادة الثانوية، والجنس، وتم استخدام الأدوات الآتية: مقياس استراتيجيات التعلم إعداد (بنترش

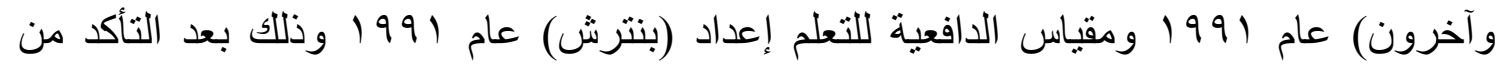
صدقهما وثباتهما، وتكونت عينة الدراسة من( • ج ) طالبأ وطالبة من طلبة كلية التربية الثالثة.

$$
\text { ومن أهم النتائج التي توصل إليها البحث: }
$$

ا ـ وجود علاقة ارتباطيه ذات دلالة إحصائية بين درجات الطلبة على مقياس استر اتيجيات التعلم ودرجاتهم على مقياس دافعية التعلّم.

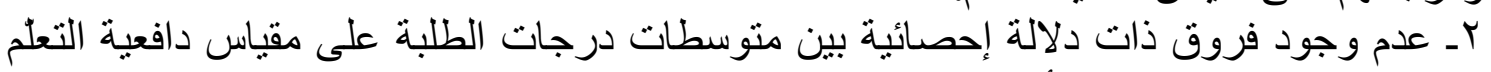

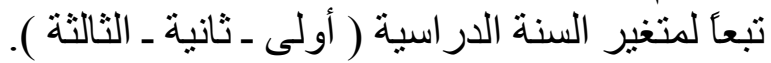

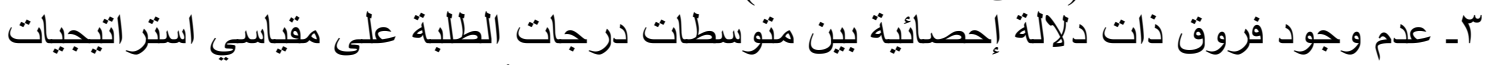

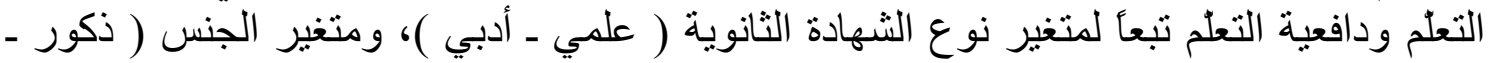
عـ وجود فروق ذات دلالة إحصائية في استر اتيجيات التعلم لدى أفر اد عينة البحث تبعأ لمتغير السنة الدر اسية لصالح الطلبة في السنة الأولى.

مقدمة البحث:

لم تعد المعرفة غاية في حد ذاتها بل أصبح التركيز على المفهوم الوظيفي لتلك المعرفة .

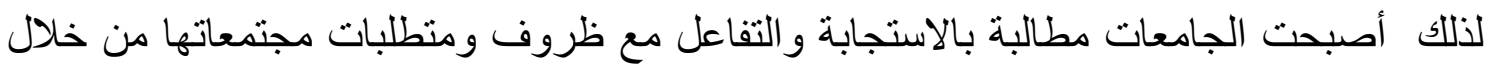

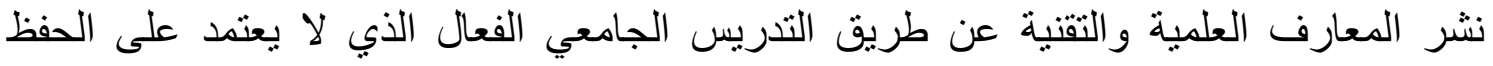
و التلقين والتلقي السلبي، و إنما يعتمد على النقاش و الحوار الفكري و الفهم والنقد. 
إن سمات هذا العصر تتطلب أفر اداً يمتلكون القدرة على التعلم الذاتي والمستمر، ويستخدمون استر اتيجيات متعددة أثناء تعلمهم، وهذا لا يتأتى إلا إذا كان الفرد مدفو عأ بدافعية داخلية تفرضها البيئة التعليمية بحيث تحثه على التعلم والاستمرار به، فلم يعد هناك زمن محدد للتعلم وارتياد

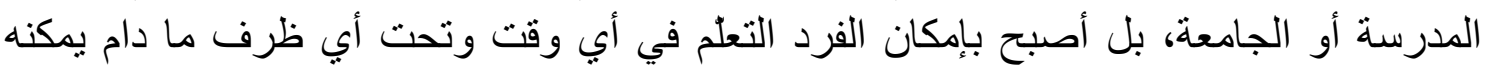

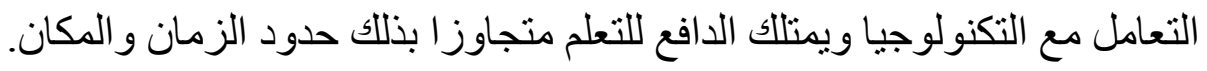

وقد تؤثر المناهج الدراسية التي يتم حشوها وتحميلها بالمعلومات و المواضيع الزائدة علي أساليب واستر اتيجيات التعلم، حيث يرى كيمبر وبليونج أن طبيعة المهمة تؤثز على النى اختيار

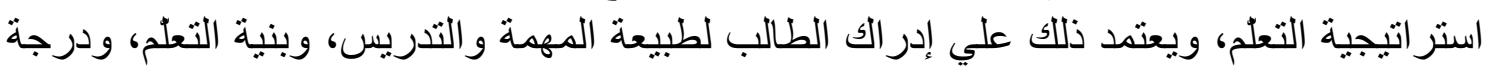

اهتمامه الثخصي بالمهمة. (Kember\& Pleung ,2003, 376-398)

و تضيف ميللر (Miller,2001,p.118) أن دافعية الطلاب و أداءهم يتحسنان عندما يتم تعديل أسلوب التعلم بحيث يلائم ميولهم، وتوصي بضرورة تحمل التربويين مسؤولية فهم تتوع طلابهم، و تقديم المعلو مات بطرق متعددة بهدف التكيف مع كافة ميول الطلاب.

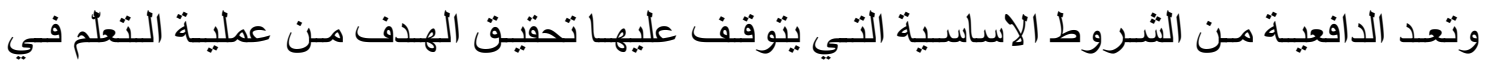

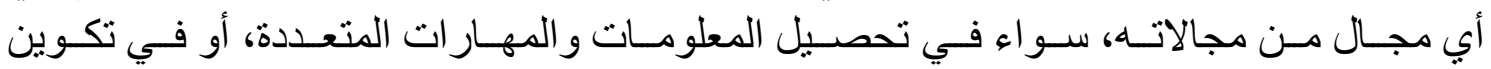

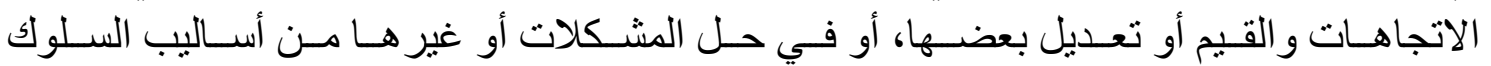

المكتسبة.

و الدافعية على علاقة بميول الطالب فتوجه انتباهه إلى بعض النشاطات دون أخرى، وهي على ألى

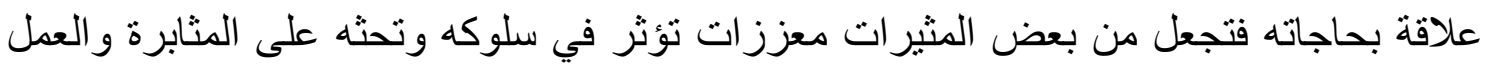

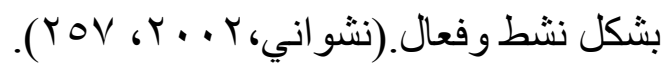

و هناك تداعيات كثيرة في العملية التعليمية تحول دون إنارة الدافعية لدى الطلبة منها أساليب التلقين المتبعة في التدريس، وضعف استجابة المناهج الدراسية للتطورات الحادثة في مفاهيم و ومهار ات التعلم، ومن أهمها مفهوم التعلم الذاتي، و إن تعليمنا الر اهن يكتفي في التدريس و الامتحان

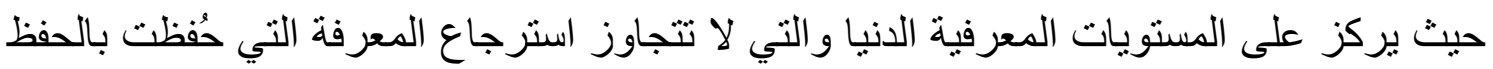

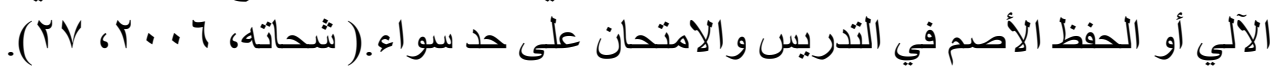

فضلا عن جمود التعلم وغياب التنافس بين الطلبة في التحصيل العلمي، وذللك لتركيز وسائل

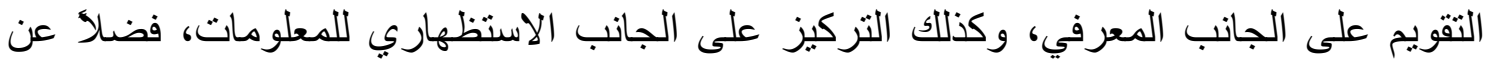
غياب وسائل التشويق في التدريس، أي غياب التقنيات التعليمية الحديثة، التي تساهم في إثارة الدافعية للتعلم.

كل ذلك قد يؤثر سلبا على تبني استر اتيجيات تعلم فعالة من قبل المتعلمبن، ولذلك جاءت هذه

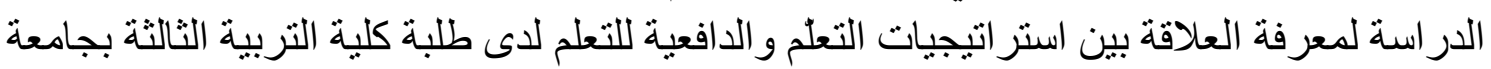




\section{مشكلة البحث:}

إن التعلم الجيد يتضمن تعليم الطلبة كيف يتحلمون وكيف يتذكرون ويحفظون، وكيف يفكرون، وكيف يثيرون دافعية أنفسهم، ويتفق الكثير من المربين على أن تعليم الطلبة كيف يتعلمون هو أمر

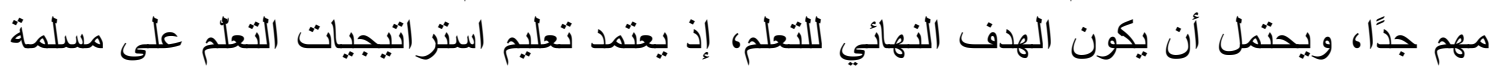
تقول بأن نجاح الطلبة بعتمد إلى حد كبير على كفاياتهم في التعلم آخذين بعين الاعتبار الاعتماد على دئى

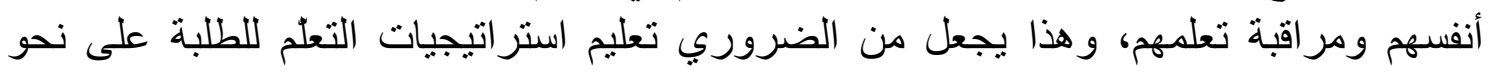

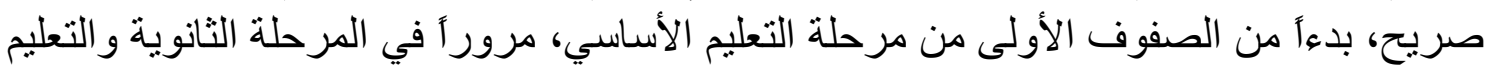

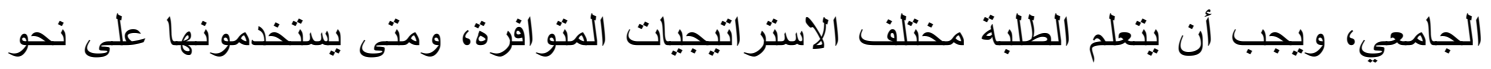

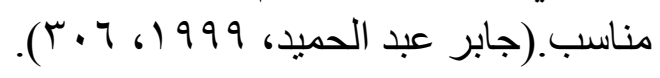

ولقد تزايد الاهتمام لدى كثير من الباحثين بدراسة الاستراتيجيات التي يتعلم بها الطلبة في

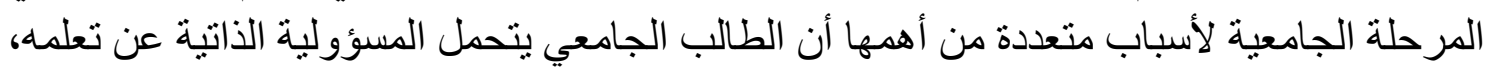

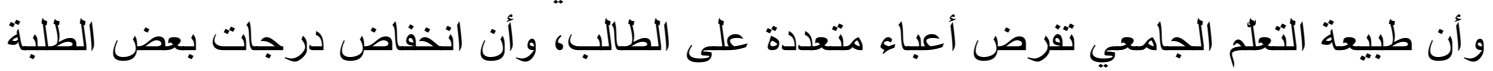

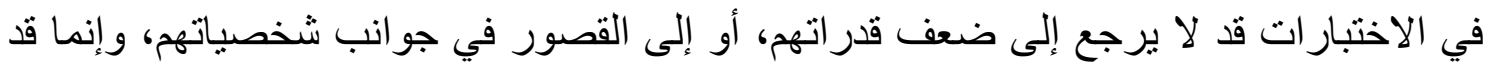

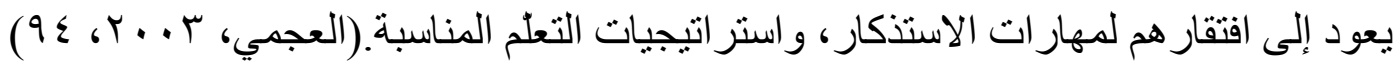
وتؤكد الدراسة المتعددة على ضرورة إتاحة الفرص المناسبة للطلبة المعلمين للتدرب في

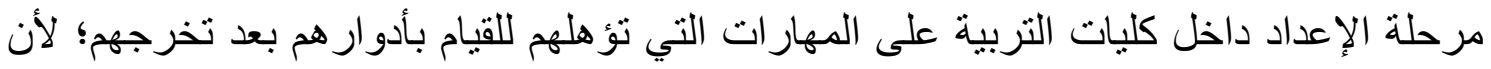
امتلاكهم لهذه المهار ات تعد مؤشراً لنجاحهم؛ خاصة وأن أن الفرد لا يمكن أن يختزن في ذاكرته معلومات كافية لاستخداماته ما لم يستخدم تللك المعلومات في مواقف جديدة يواجه بها بها تحديات

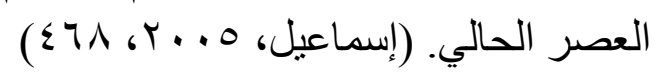

وتؤكد الاتجاهات الحديثة في التعليم والتعلم باستمرار على مساعدة الطلبة على أن يتعلموا كيف

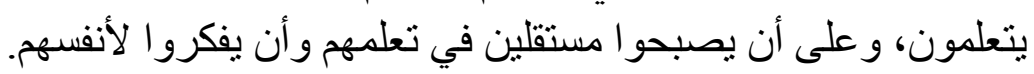

وتعد الدافعية من العوامل المهمة لقدرة المتعلم على الانجاز والتحصيل لكونها على علاقة بالمتعلم فتقوم بتوجيه انتباهه إلى بعض النشاطات التي تؤثر في سلوكه وتحثنه على العثل العمل و المثابرة

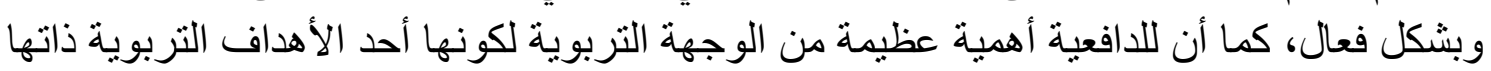
و إن استثارة دافعية الطلبة تجعلهم يمارسون نشاطات معرفية خارج نطاق العمل المدرسي وفي لإني

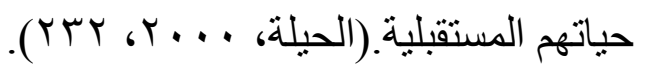

و التدريس الناجح يضم مجموعة من الفعاليات التربوية القادرة على تحقيق التعلم لدى الطلبة، إلا أن التعلم، مع ذلك يبقى مشرو عأ شخصياً يقع على عاتق المتعلمين أنفسهم. فهو مسؤولية ذاتية

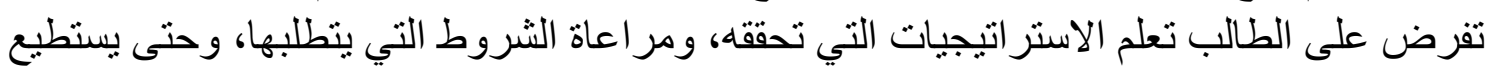

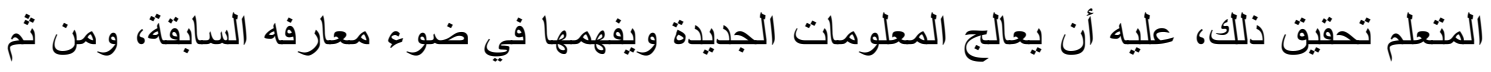


يكامل بينها وبين القديمة، ويعيد بناءها معأ من جديد، بغية استخدام المعرفة المتكونة في تعلم جديد

و مزج تعليم استر اتيجيات التعلم، مع العمل على توظيف العو امل التي تؤدي إلى إثارة الدافعية

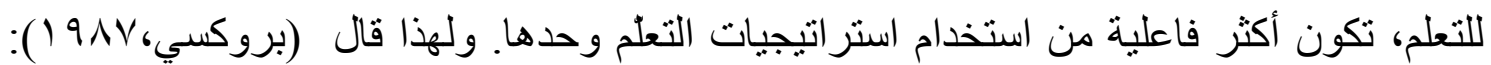

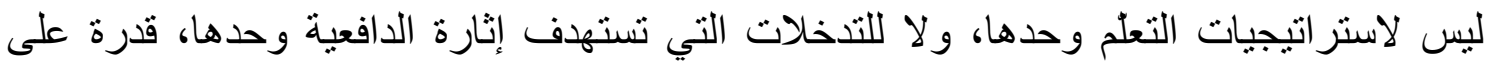

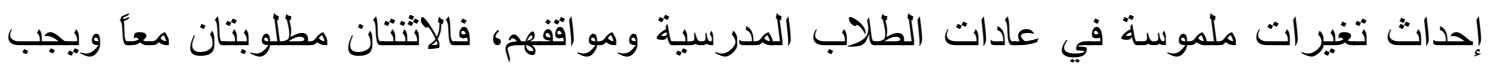

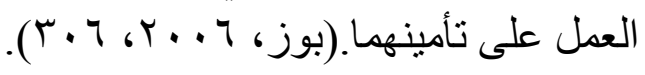

وجامعاتنا لم تتغير كثيرَ في هذا المستوى حيث لا تز ال تخرج أجيالا قادرة على الحفظ الصم عن ظهر قلب فقط من دون فهم أو استيعاب، وهي أبعد ما تكون عن أهداف التعليم الجامعي في

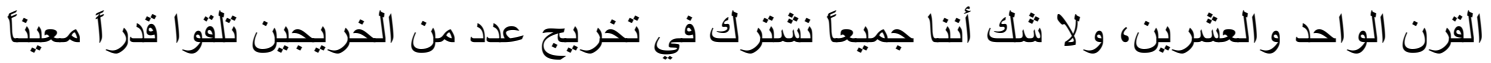

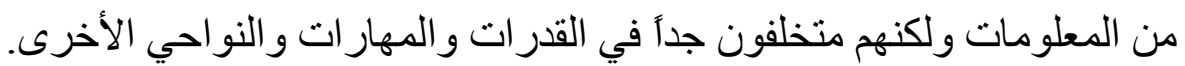

وبعد اطلاع الباحث على عدد من الدر اسات العربية والأجنبية التي تناولت استر اتيجيات التعلم

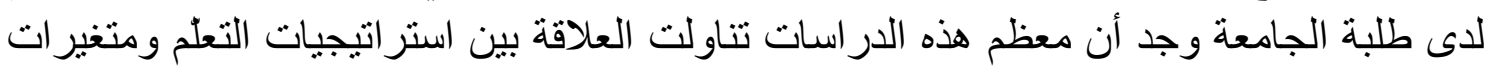

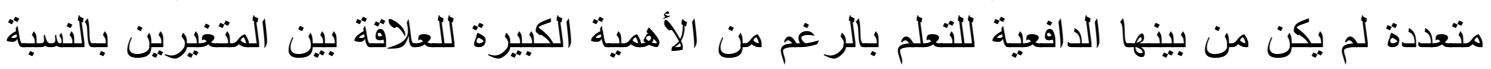

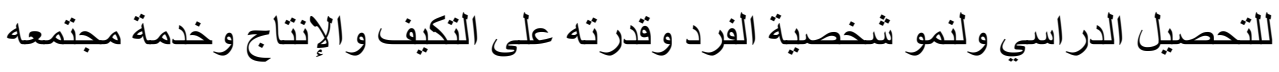
لذللك جاء هذا البحث في الكثف عن العلاقة بين استر اتيجيات التعلم و الدافعية للتعلم لدى طلبة كلية

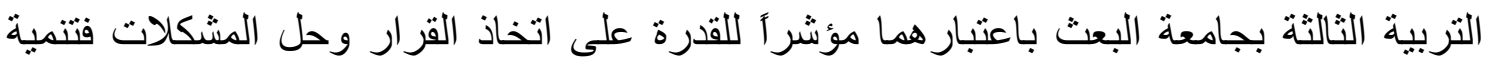

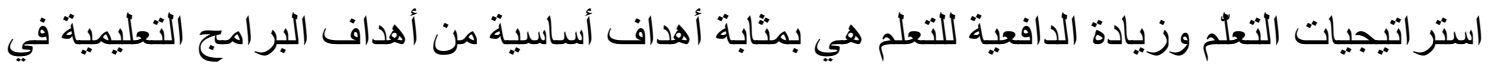
الجامعات بشكل عام وكليات التربية بشكل خاص، ومما سبق يمكن صياغة مشكلة البحث في ضورء

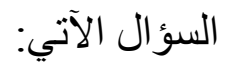

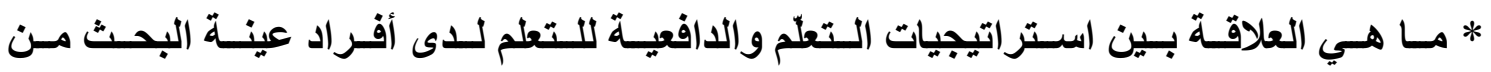

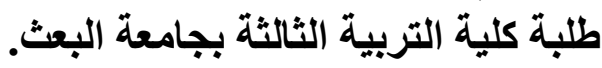

أهمية البحث والحاجة إليه: تكمن أهمية الدر اسة الحالية فيما يلـي:

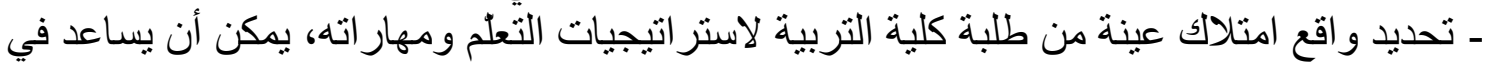

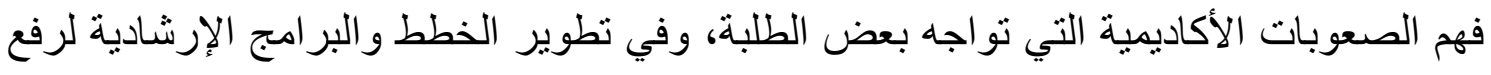

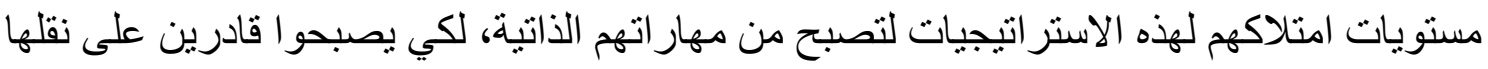

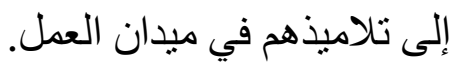

ـ در اسة العلاقة بين استر اتيجيات التعلم و الدافعية للتعلم تساعد على وضع بر امج تعليمية تساعد في

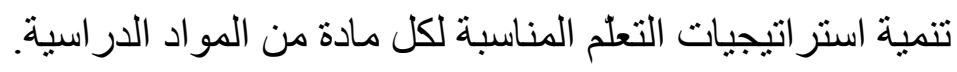

ـ إفادة مصمدي بر امج تدريب معلمي الحلقة الأولى؛ بتزويدهم بمعلومات دقيقة عن استر اتيجيات التعلم المفضلة لدى الطلبة؛ بحيث تساعدهم على تطوير الخطط الدر اسية. 
أهداف البحث: يهذف البحث الحالي إلى ما يلي: 1 ـ معرفة العلاقة بين استراتيجيات التعلم ودافعية التعلم لدى طلبـة كلية التربية الثالثة بجامعة آبـ معر فة الفروق في استر اتيجيات التعلم ودافعية التعلم لدى طلبة كلية التربية الثالثة بجامعة البعث

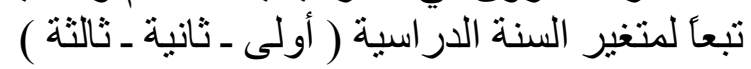

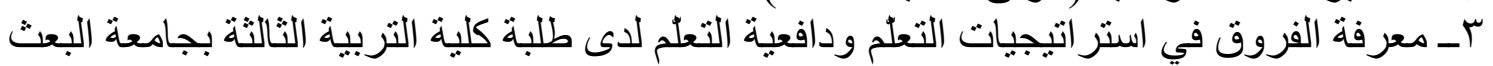

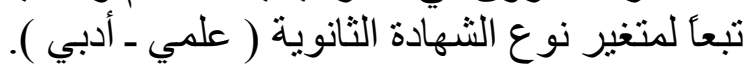
عـ معرفة الفروق في استر اتيجيات التعلم ودافعية التعلم لدى طلبة التبة كلية التربية الثالثة بجامعة البعث تبعأ لمتغير الجنس (ذفوفة في الفور - إناث ).

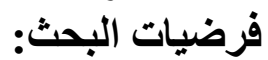
ا ـ لا توجد علاقة ارتباطيه ذات دلالة إحصائية بين درجات أفر اد العينة على مقياس استر اتيجيات التعلم ودرجاتهم على مقياس دافعية التعلم.

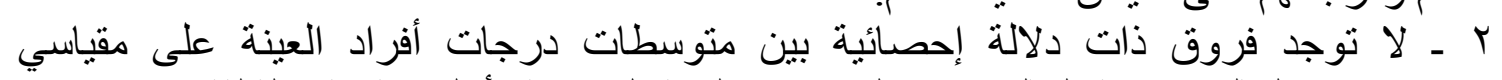

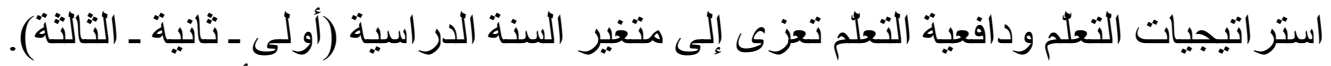

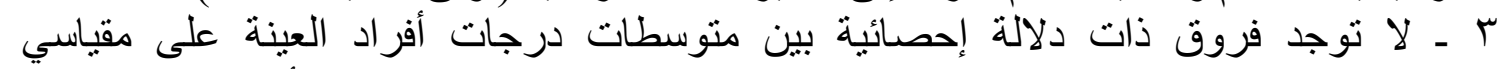

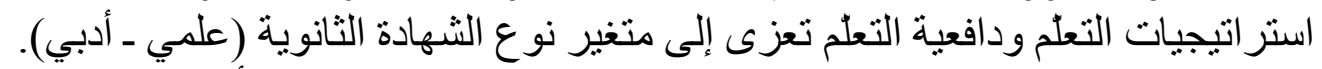

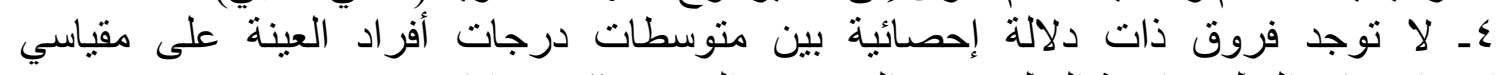

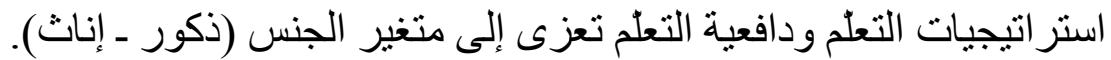

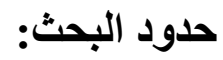
اـ الحدود المكانية: يشتمل البحث الحالي على عينة مسحوبة من طلبة كلية التربية الثالثة ( قسم

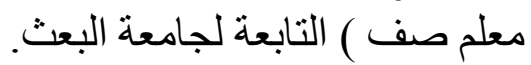

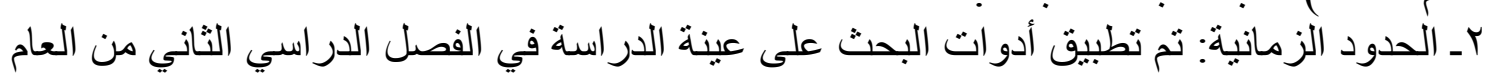

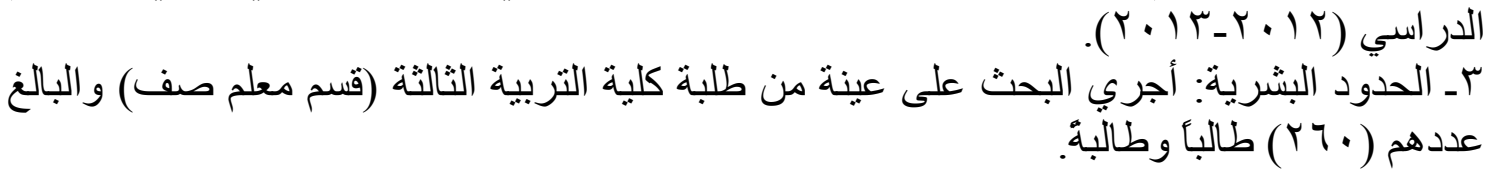

تحديا المصطلحات:

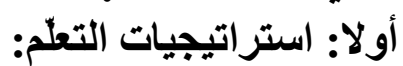
عرفها مالكود (1911) (191): بأنها طريقة معالجة الفرد اللمشكلات التربوية والاجتماعية بالاعتماد على الخبرات التي تتو افر في مخزونه المعرفي والبيئة الخارجية المؤثرة في التعليم.( قطامي

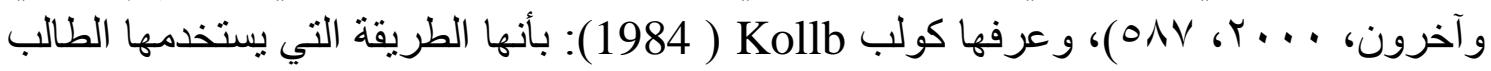
في إدر الك ومعالجة المعلومات أثناء عملية التعلم.(kollb,1984;pp259-289). التعريف الإجرائي: هي الطرائق التي تؤدي بالطلبة إلى تعلم السلوك المفضل في اكتساب

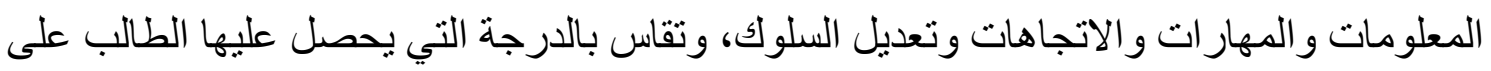
مقياس استر اتيجيات التعلم المستخدم في هذه الدر اسة. 
ثانيا: الدافعية للتعلم: n n

يشير مفهوم الدافعية للتعلم إلى مثابرة الطلاب واستمتاعهم بالتعلم والاهتمام بكل ما هو جديد،

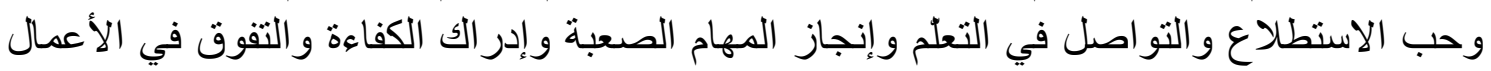
التي يقومون بها (Gottfried ,1994,p.18).

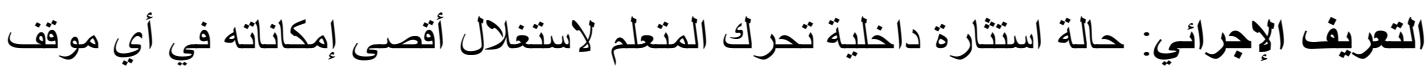

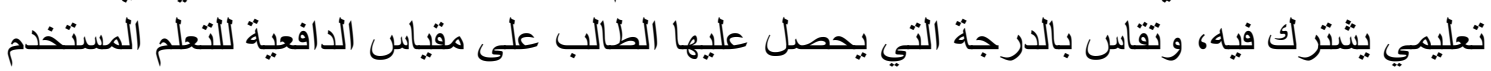
في هذه الدر اسة.

كلية التربية الثالثة: هي إحدى كليات جامعة البعث في الجمهوريـة العربيـة السورية أنشئت عام

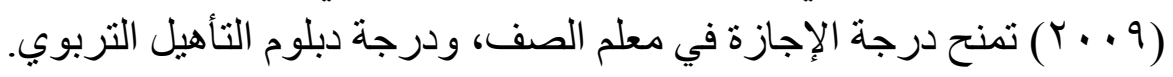

$$
\text { الجاتب النظري والاراسات السابقة: }
$$

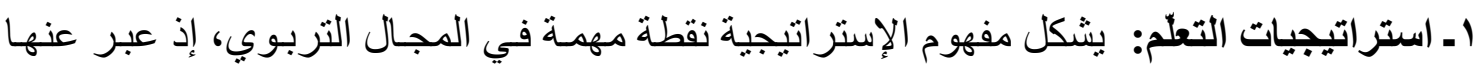

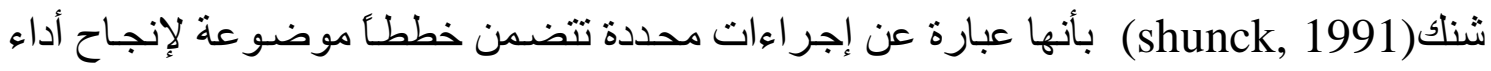

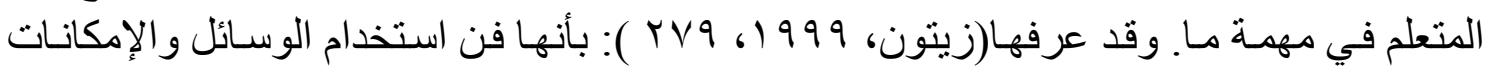
المتاحة بطريقة مثلى لتحقيق الأهداف بدرجة منئ عالية من الإتقان.

وينظر إلى الإستر اتيجية بأنها خطة محكمة البناء ومرنة التطبيق؛ فهي حلقة متكاملة تقريباً، وسلسلة

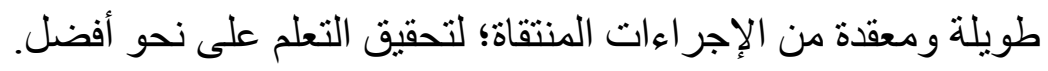

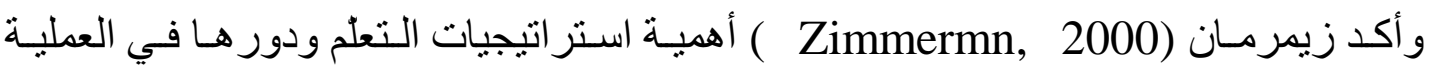

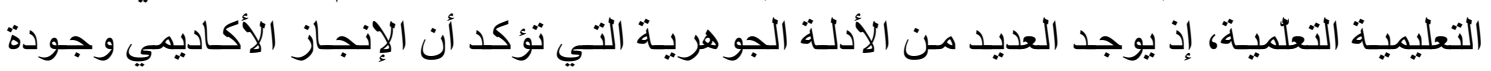

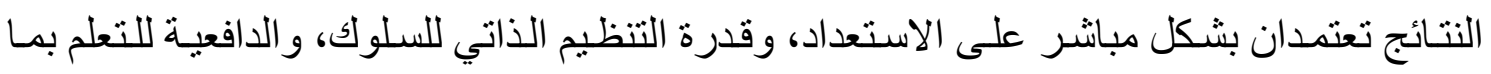
يتناسب مع الموقف التعليمي.

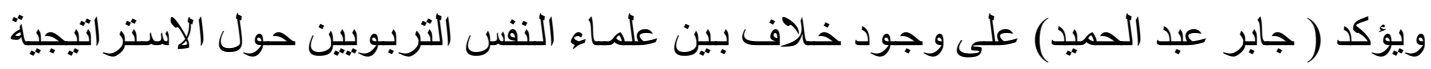

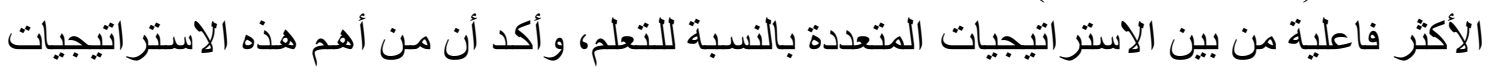

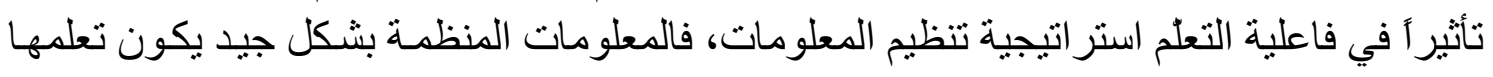

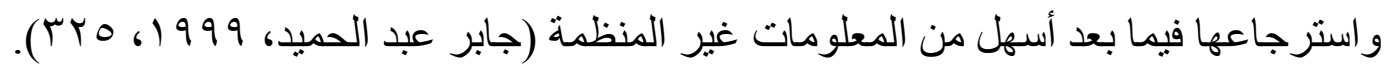

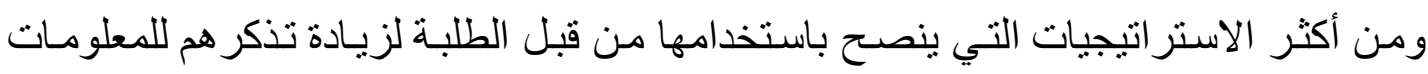

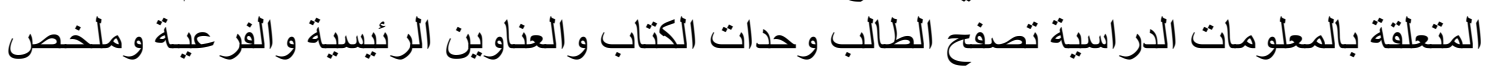

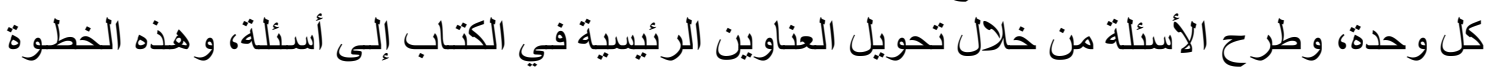

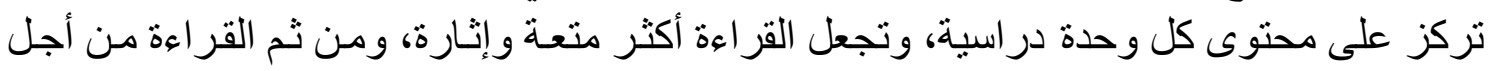

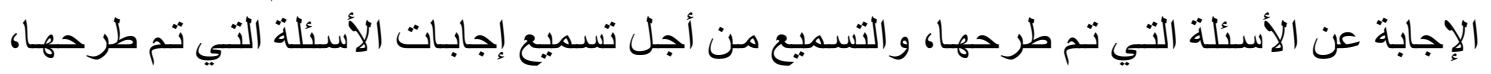

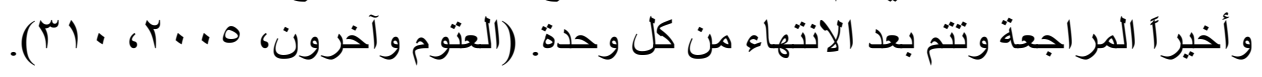


وتعد استر اتيجية طلب المساعدة من الاستر اتيجيات التي تعمل على تتظيم السلوك، وتتضمن

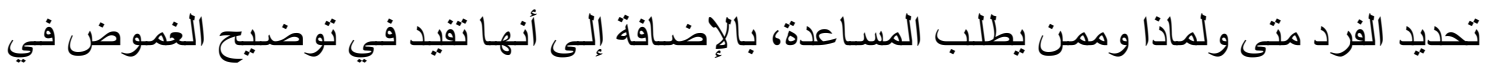

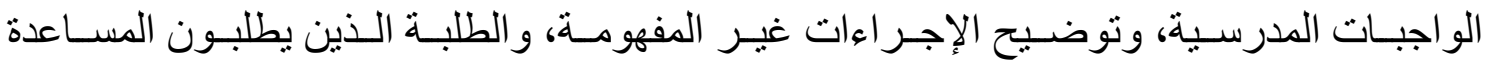

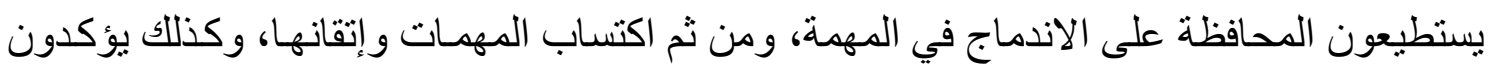
إدر اكاتهم لأنفهر باعتبار هم متعمين ومنجزين الأهداف. (Pintrich, 2000).

وتعد استر اتيجية تعلم الأقران ذات أثر ايجابي على التفاعل الاجتمـاعي، فالمتعلم يبني المعرفة

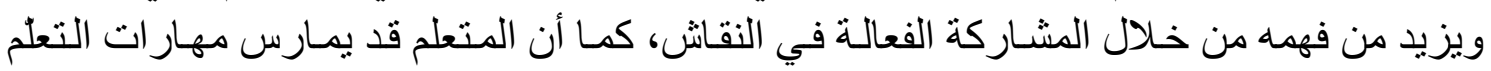
التعاوني و التعلم التشاركي مع الآخرين، ويجب عليه فيه أن يعرف متى يحصل على المساعدة ومن من كن يحصل عليها. (Pintrich, 2000).

وتثير استر اتيجية إدارة بيئة الدر اسة ووقتها إلى تخطيط وتتظيم الوقت، مما يجعل المتعلم يحدد

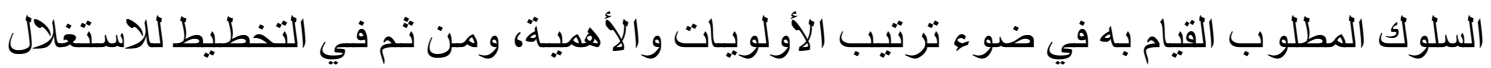
الأمثل للوقت، ويجب ترتيب البيئة من قبل المتعلم بصورة تمكنه من تركيز الانتباه و التغلب على المشتنات.Wolters \& Rosenthal, 2000).

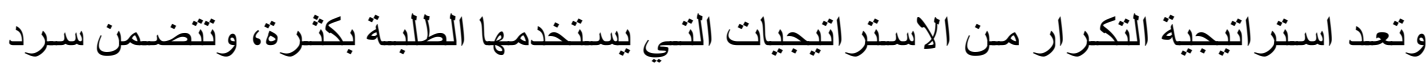

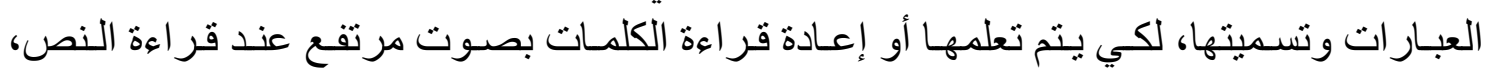
وتسـاعد الطلبة على استرجاع المعلومـات المحددة عندما يطلب منهم ذلك. (Pintrich \& De). Groot, 1990)

و أخير آ تعد استر اتيجية التلخيص ووضع خطوط تحت الأفكار المهمة من الاستر اتيجيات الهامـة جدأ للتعلم، فضلا عن كتابة معلومات مختصرة حول الفكرة الأساسية التي بدرسها الطالب.

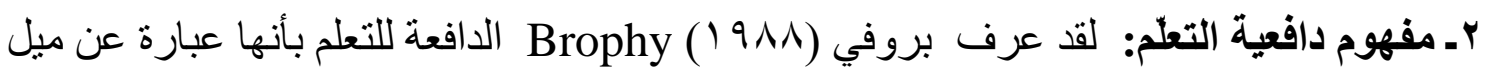
الطلبة إلى القيام بأنشطة علمية يؤدي النجاح فيها إلى الحصول على مكافئ مكآت تثبع الحاجات الداخلية

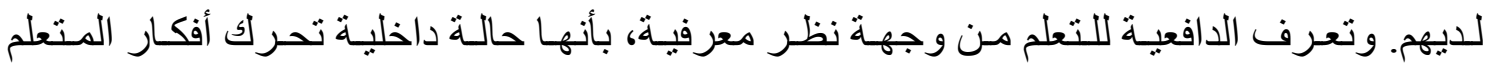

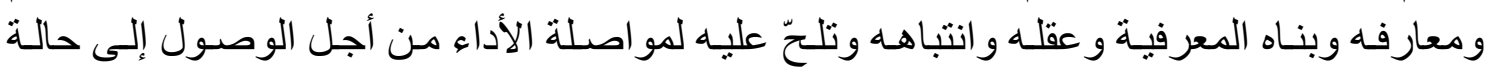

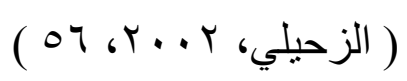

ويمكن أن نعرّن الدافعية للتعلم بأنها: حالة داخلية لدى المتعلم تستثير سلوكه وتدفعه للانتبـاه إلى الى الموقف التعليمي، و القيام بنشاط موجه و الاستمر ار في هذا النشاط حتى يحدث التعلّم. بـ أهمية الدوافع في المجال التربوي: تعد الدو افع مسبية للسلوك و لا سلوك بدون دافعية أيـأ كانت

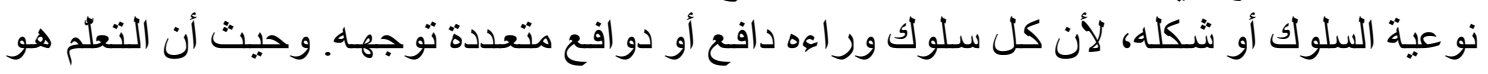

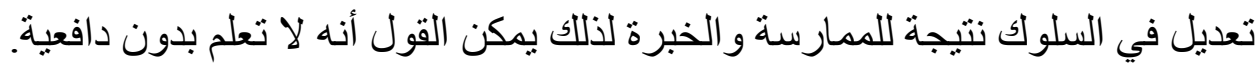


وبما أن الدو افع تعتبر مسببة للسلوك، فيرجـع إليها أي نشـاط يصدر عن الكائن الحي، أي أنها

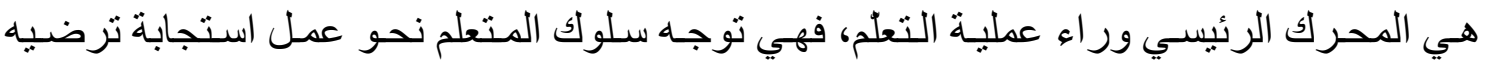
وتساعده على حل المشكلات التي تو اجهه، وفي حال عدم وصول المتعلم إلى مثنل هذه الاستجابة فئة فإنه يعمل جاهداً لإشباع هذه الدو افع وحل المشكلة الموجودة، وبالتالي يستمر نشاطه من أجل حله حلها. و أكد بول (Ball) أن الدافعية العالية تزيد من قدرة الأفر اد على ضبط أنفسهم في العمل الدؤوب

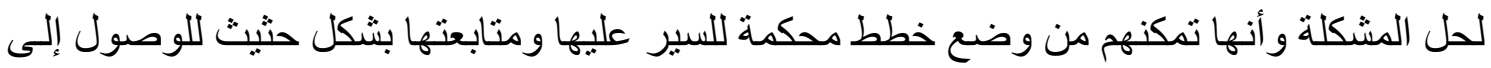
الحل، ويمتاز الأفر اد ذووا الدافعية العالية بقدرتهم على وضع خطط مسط مستقبلية معقولة ومنطقية في

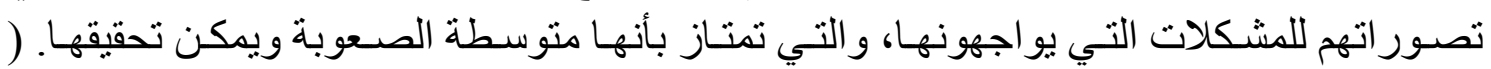

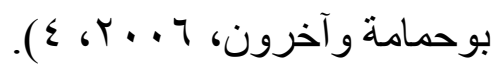

ويذكر(Hartnett \& Dron, 2011) أن الدافعية هي العملية الموجهة نحو حفز المتعلم وزيـادة

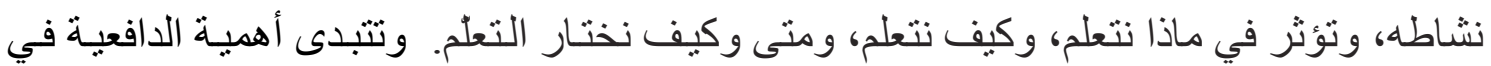

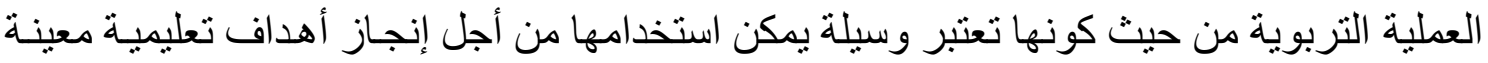

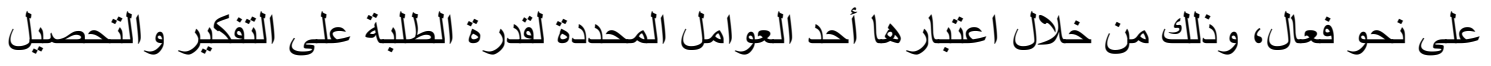

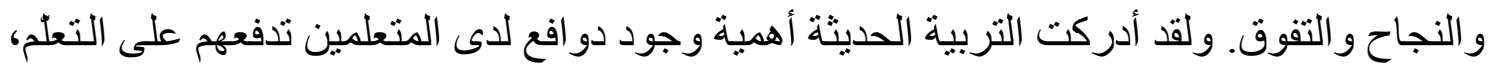

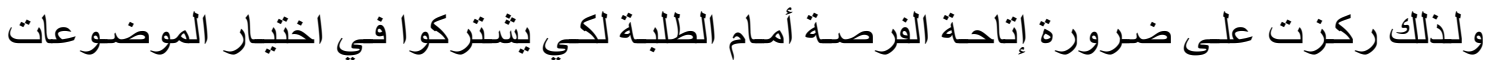
و المشكلات التي تمس نو احي هامة من حياتهم، وكذللك ركزت على ضرورة توزئ توزيع المسؤوليات على الطلبة حتى يشعر كل منهم بوجود دافع حقيقي يدفعه إلى التعلّ.

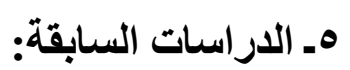

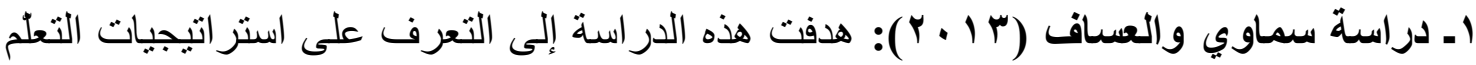

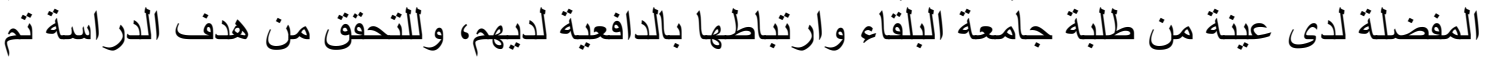

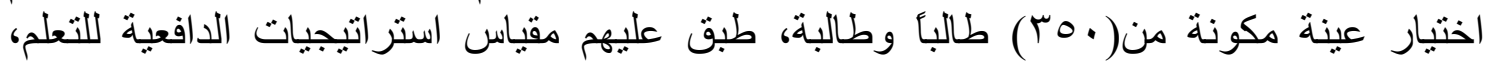

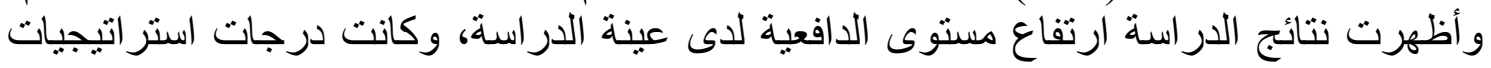

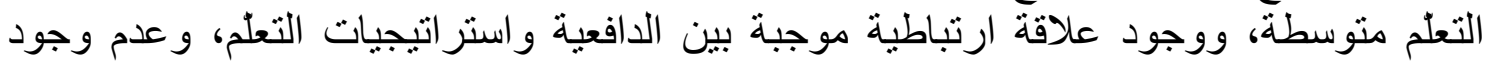

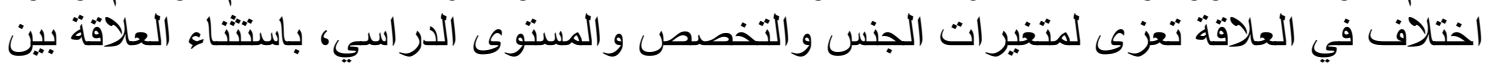

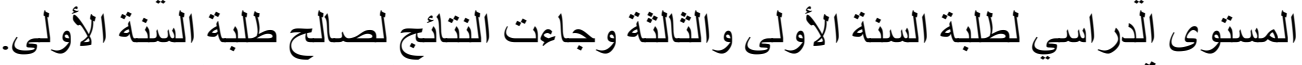

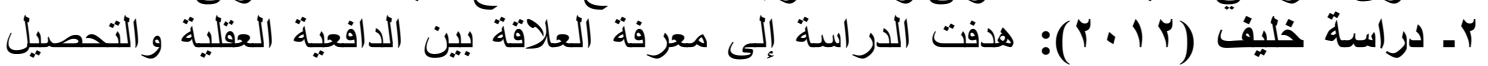

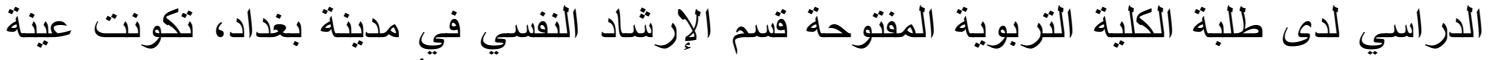
البحث من ( • 7) طالبأ وطالبة طبق عليهم مقياس الدافعية العقلية، وقد أظظهرت الإنة النتائج وجود دافية دافعية عقلية عالية لدى عينة البحث، ووجود علافة بين درجات الدافعية العقلية ومهار ات التعلم و التحصيل وحفيل

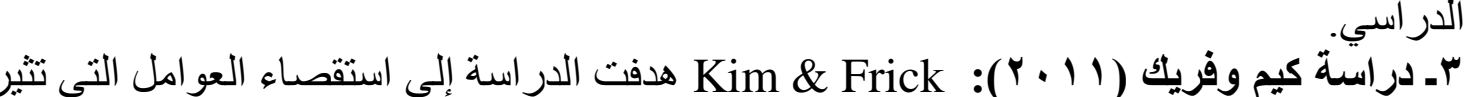

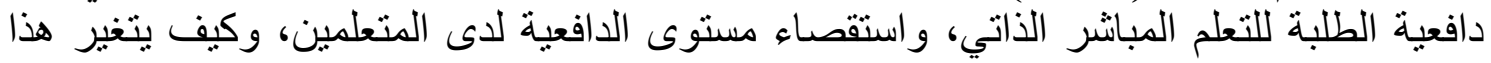

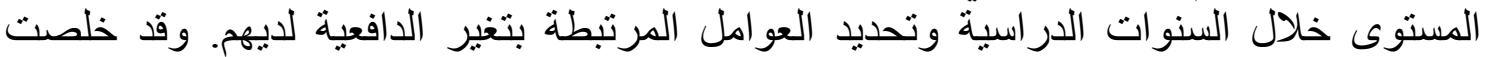

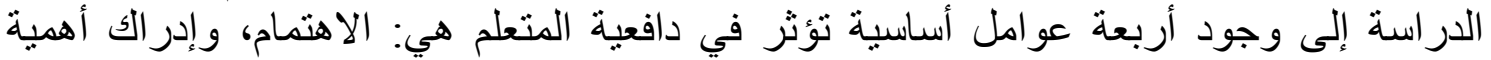

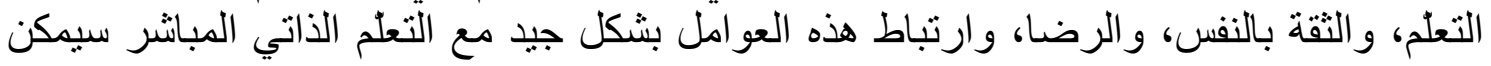


المتعلم من تحقيق أهداف التعلم بنجاح، كما خلصت الدر اسة إلى أن دافعية الطلبة تزداد مع انتقالهم

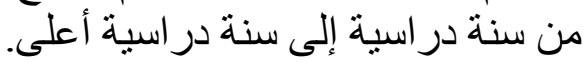

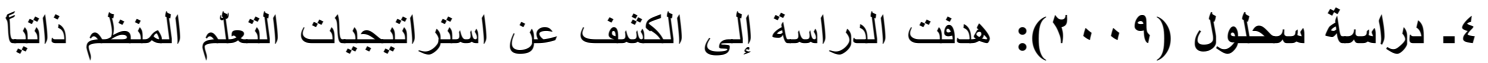

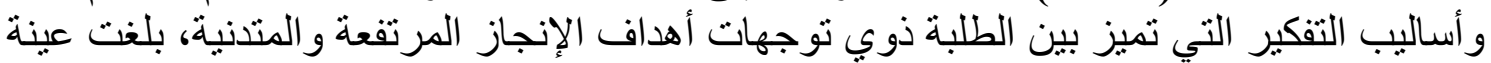

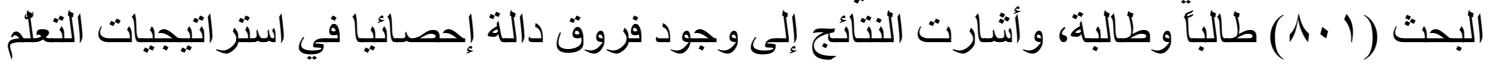

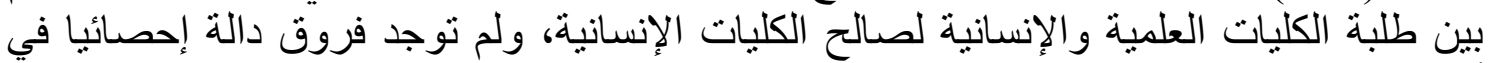

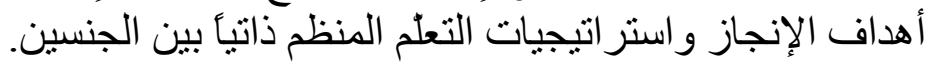

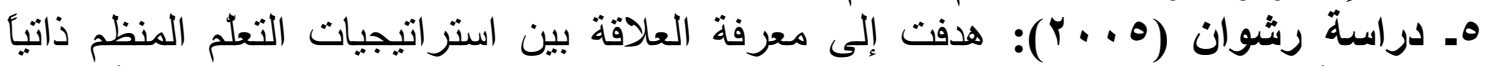

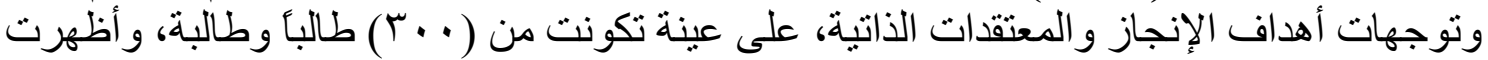

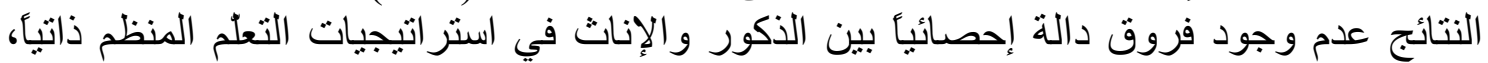

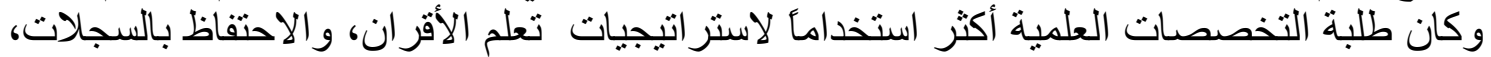
و التقويم الذاتي.

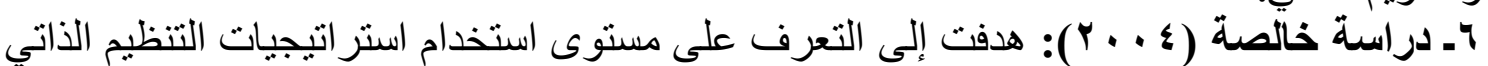

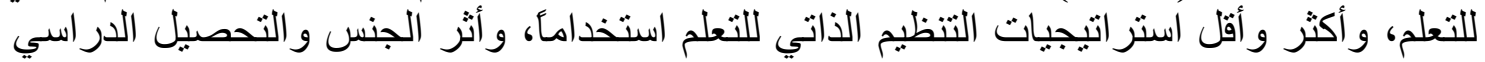

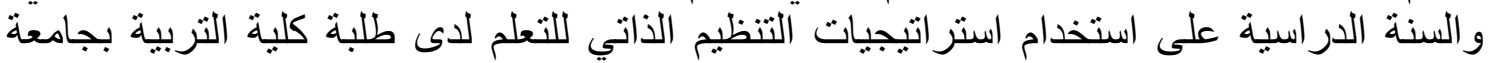

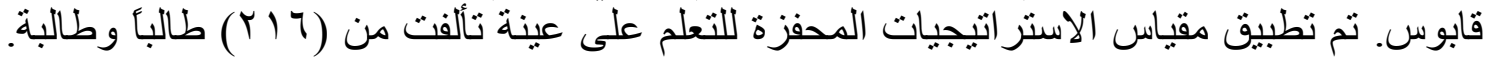

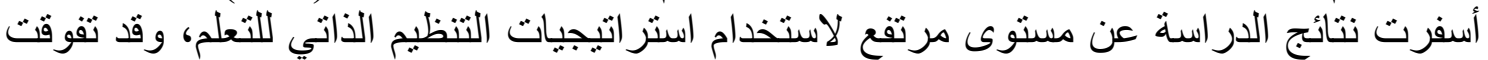

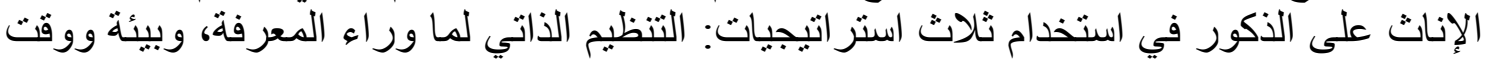
التعلم، وتفوق طلبة السنتين الأولى والثانية على السنوات الثالثة والثرابعة في في استخدام استر اتيجيات

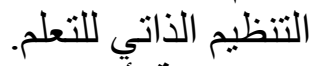

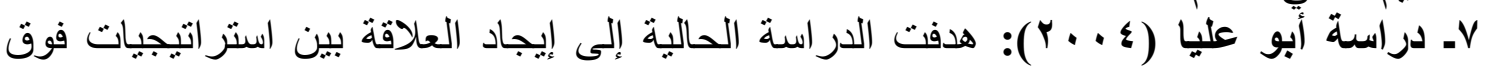

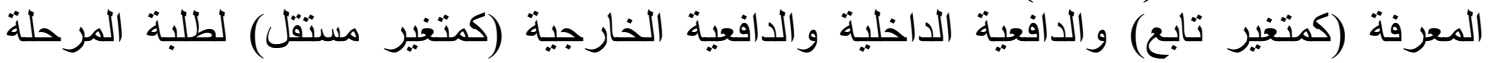

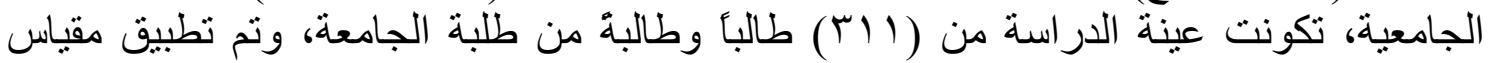

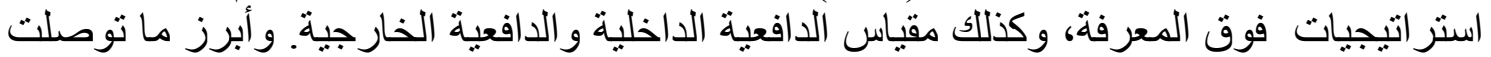

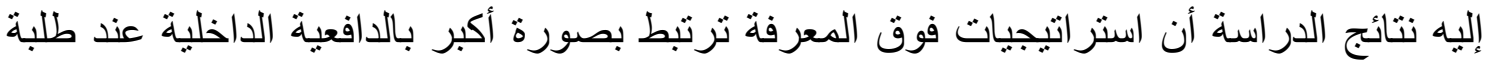

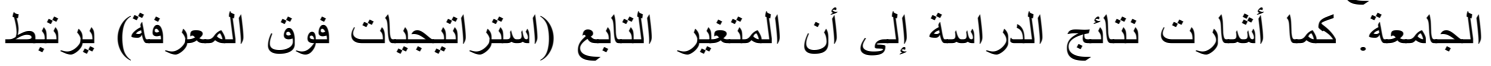

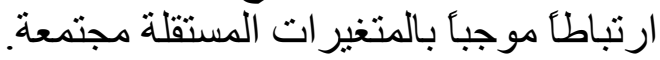

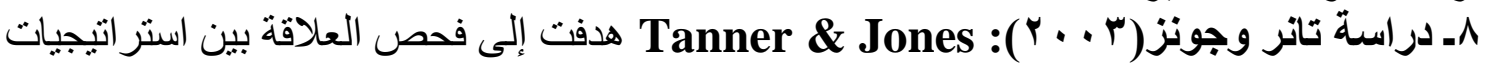

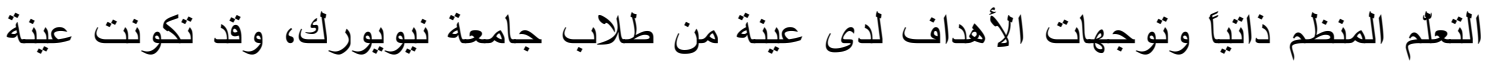
الدر اسة من( • 1 ( ) طالبأ وطالبة من طلبة السنة الأولى استجابو المقياس استر اتيجيات الدافعية للتعلم (MSLQ) و استر اتيجيات التعلم المنظم ذاتيأ وتوجهات الأهداف، وارتبطت نوجهات أهداف الإنجاز بالأداء الصفي القائم على استراتيجيات التعلم المنظم ذاتيا، وعدم وجود أثر للجنس في استخدام استر اتيجيات التعلّ.

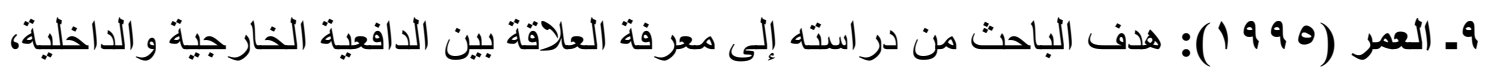
ومعرفة أثر كل من الجنس والتخصص على الدافعية، وتكونت عينة الدراسة من (Y0. (Y) طالباً

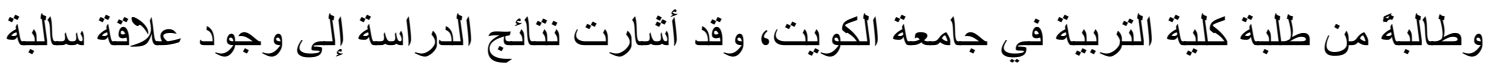

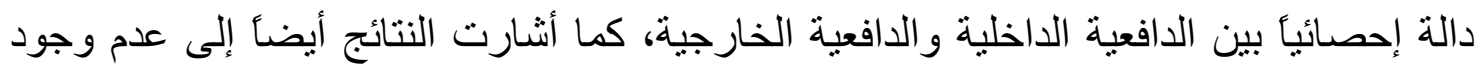


فروق دالة بين الذكور والإناث في الدافعية الداخلية والخارجية، وعدم وجود فروق دالة بين التخصصات المختلفة في الدافعية. التعليق على الار اسات السابقة:

يلاحظظ مـن خـلال عـرض الدر اسـات السـابقة أن أغلبيـة الدر اسـات السـابقة توجهـت نحـو طلبـة

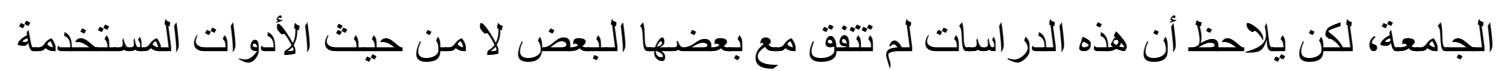

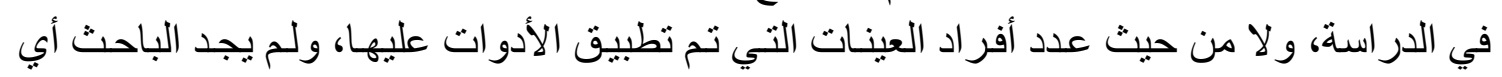

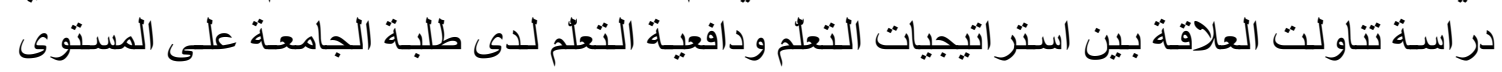

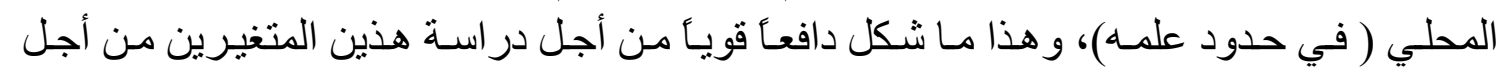

الوصول إلى فهم أفضل للعلاقة بينهما. إجراءات البحث

أولاً ـ منهج البحث: لقد استخدم الباحث المنهج الوصفي التحليلي لأنه أكثر ملاءمـة لأهداف البحث

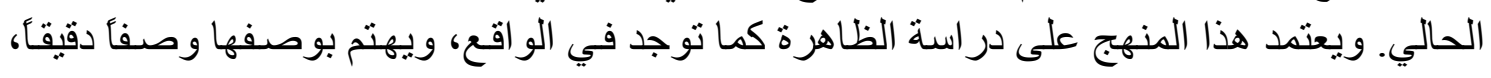

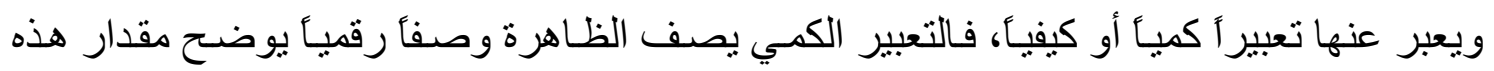

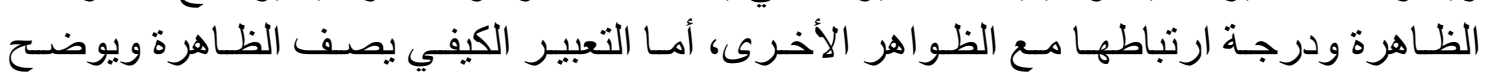

خصائصها.

ثانياً. مجتمع البحث: تحدد مجتمع البحث الحالي بطلبة كلية التربية الثالثة قسم معلم صف المسجلين

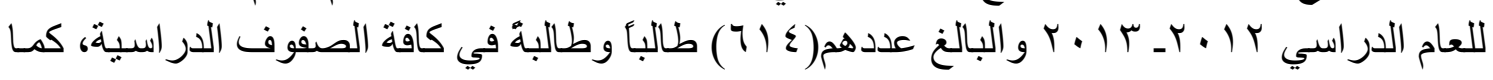
هو موضح في الجدول رقم (l) (l) جدول( ) بيبن حجم مجتمع البحث

\begin{tabular}{|c|c|c|c|}
\hline المجموع & إناث & ذكور & السنة \\
\hline$Y \cdot V$ & 177 & \&1 & الأولى \\
\hline $1 \wedge \Lambda$ & 119 & 79 & الثانية \\
\hline ITV & $1 \cdot \varepsilon$ & Tr & الثالثة \\
\hline 94 & $7 r$ & $r$. & الر ابعة \\
\hline $71 \leqslant$ & $\leqslant 01$ & $17 \pi$ & المجموع \\
\hline
\end{tabular}

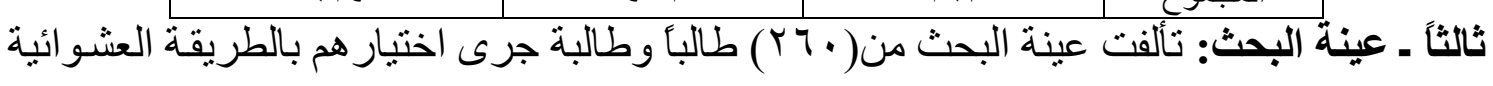

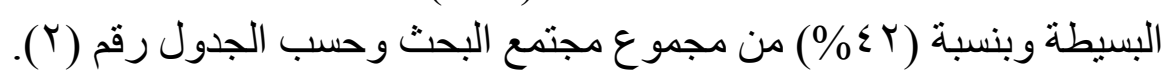


جدول (r) ييين حجم عينة البحث

خبـ اعتمـاد أداتين للبحث، بعد التأكد مـن

\begin{tabular}{|c|c|c|}
\hline النسبة \% & العدد & السنة \\
\hline$\leqslant \wedge$ & $1 \ldots$ & الأولى \\
\hline$\varepsilon r$ & ᄉ. & الثانية \\
\hline$\pi$ & ᄉ. & الثالثة \\
\hline$\varepsilon r$ & r.. & المجموع \\
\hline
\end{tabular}

صدقهما وثباتهما كما يأني:

أ ـ مقياس استراتيجيات التعلم:

أعد هذا المقياس (بنتزش وآخرون) عام الو 199 وهو عبارة عن أداة للتقرير الذاتي صدم لقياس

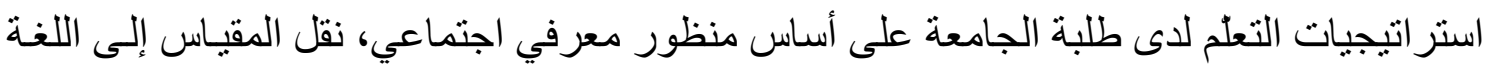

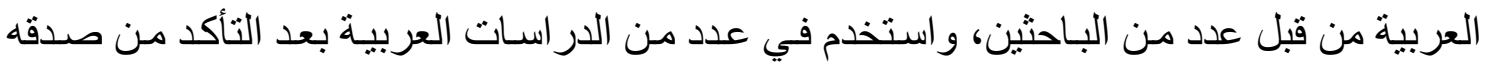
وثباته.

يتكون المقياس من(q §) عبارة، ( • ) ) عبارة منها تتعلق باستر اتيجيات التعلم المختلفة المعرفية،

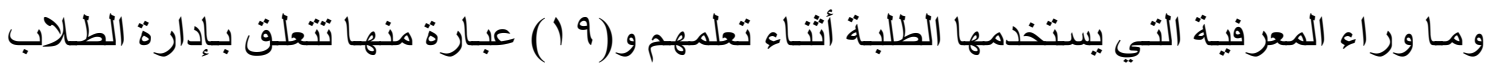
لمختلف المو ارد، ويتم الاستجابة على جميع عبار ات المقياس على مقياس متدرج من سبع نقاط من

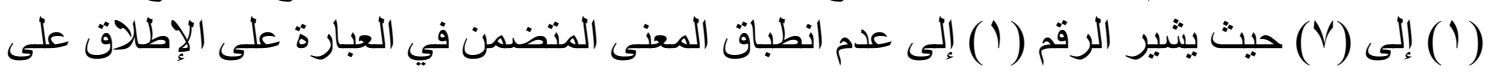

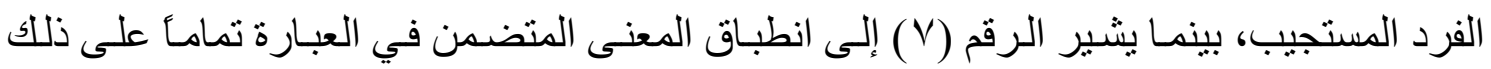
الفرد في حالة العبار ات الموجبة، وفي العبار ات السالبة فتعكس هذه الدرجات الدات.

يتمتع المقياس بثبات عالِ وصدق جيد، حيث تم استخدام أسلوب التحليل العاملي للتحقق من صدق البناء الداخلي للمقياس، كما يتمتع بصدق تنبؤي جيد لأداء الطلاب الحقيقي في المقرر ات ات الدر اسية.

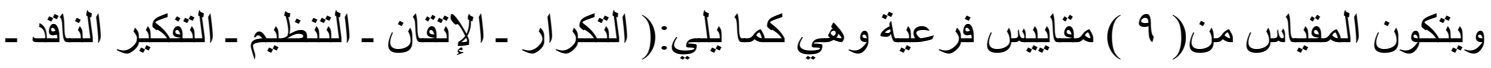
التنظيم الذاتي ـ إدارة بيئة ووقت الدر اسة ـ تنظيم الجهد ـ تعلم الرفاق ـ البحث عن عن المساعدة. ـ صدق المقياس: تم استخر اج الصدق الظاهري بعرض المقياس على مجمو عة من المختصسين في

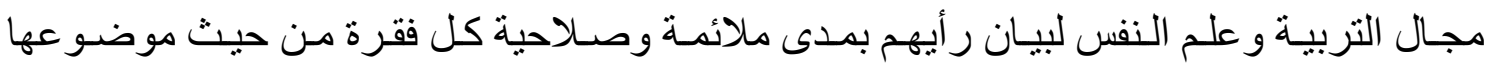
ووضوحها في قياس الخاصية التي وضعت من أجلها، لاحظ الباحث أن المقياس ملائم لتطبيقه على ولى

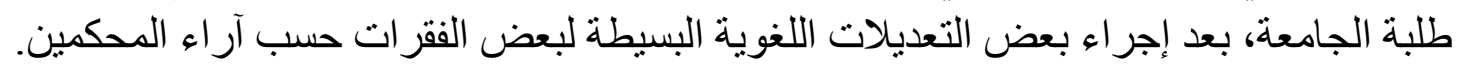
ـ ثبات المقياس: استخر ج ثبات مقياس استر اتيجيات التعلم بالطر ائق الثلاث التالية: 
ا ـالثبات بالإعادة: لحساب ثبات المقياس بطريقة إعادة الاختبار قام الباحث بتطبيق المقياس على إنى

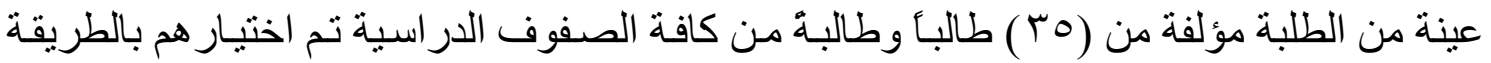

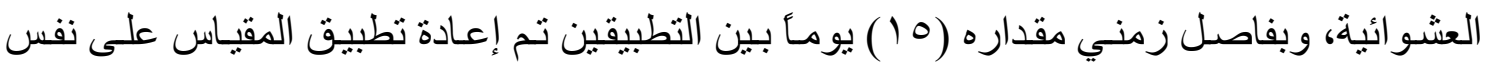

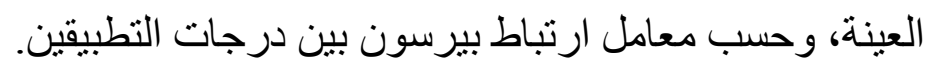
ץ-ثبات التجزئة النصفية: تم حساب معامل ثبات التجزئـة النصفية مسن العينـة نفسها ومن التطبيق

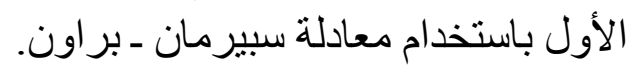

ب-ثبات الاتسـاق الداخلي بمعادلـة ألفـا كرونباخ: تم حسـاب معامل الاتسـاق الداخلي للعينـة نفسها

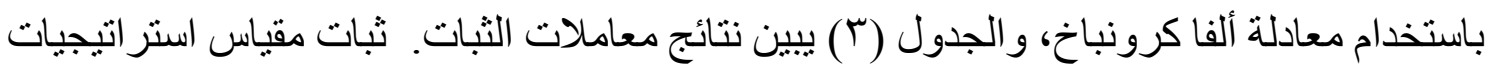
التعلم بالإعادة والتجزئة النصفية وألفا كرونباخ الناخ

\begin{tabular}{|c|c|c|c|}
\hline ألفا كرونباخ & التجزئة النصفية & الثبات بالإعادة & مقياس استراتيجيات \\
\hline$\cdot . \wedge \wedge * *$ & $\cdot . \wedge \Delta * *$ &..$\vee 9 * *$ & \\
\hline
\end{tabular}

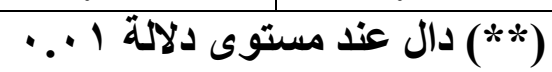

مـن النظر إلى الجدول (r) نجد أن معـاملات ثبـات الإعـادة بلغت ( V9. • )، ومعـاملات ثبـات

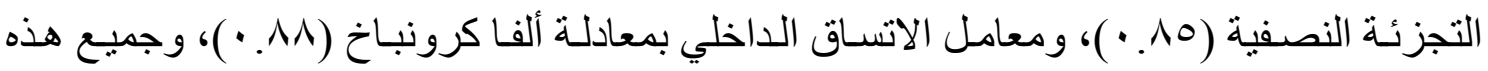

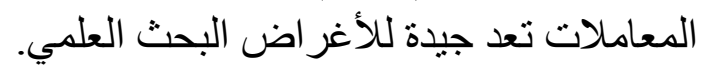

ويتضح من خلال حساب صدق وثبات المقياس بأنه يتصف بدرجة جيدة من الصدق والثبات، مما

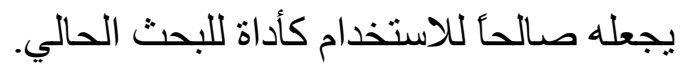

ب ـ مقياس دافعية التعلم: أعد هذا المقياس (بنترش و آخرون) عام (99 أوهو عبارة عن أداة

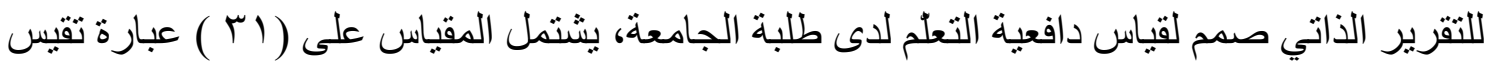

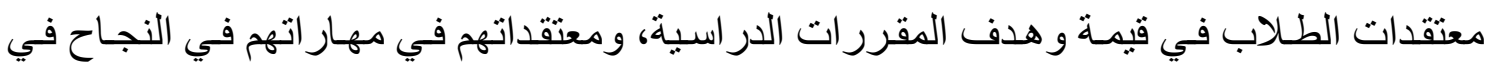

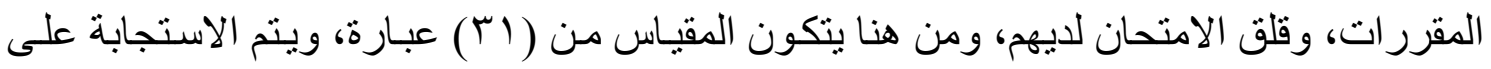

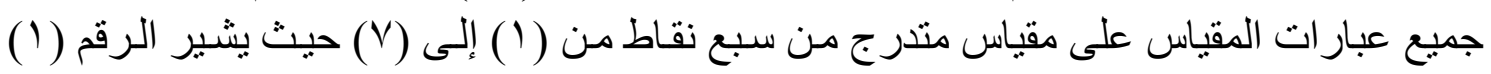

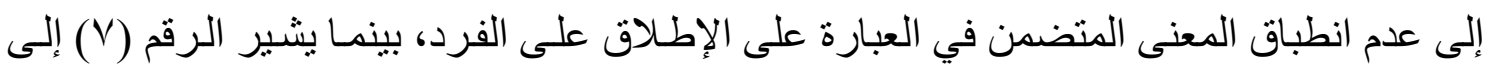

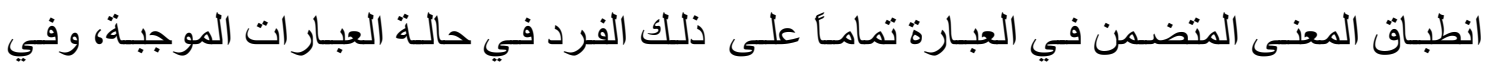

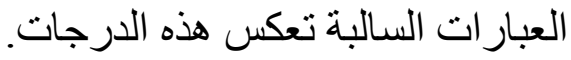

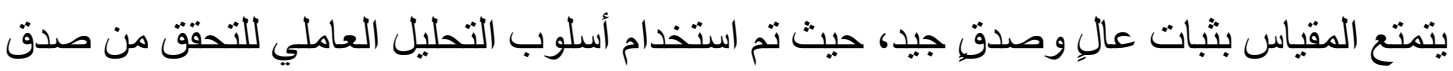
البناء الداخلي للمقياس، كما يتمتع بصدق تنبؤي جيد لأداء الطلاب الحقيقي في المقرر ات ات الدر اسية.

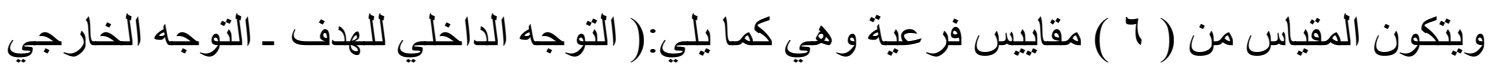
للهدف ـ قيمة المهمة ـ ضبط معتقدات التعلم ـ فعالية الذات في التعلم ـ قلق الاختبار . 
ـ صدق المقياس: تم استخر اج الصدق الظاهري بعرض المقياس على مجمو عة من المختصين في

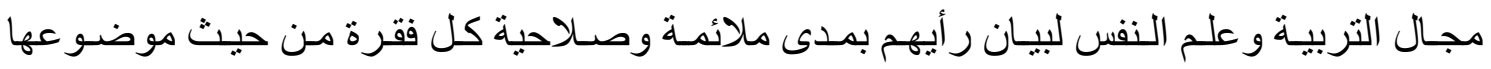
ووضوحها في قياس الخاصية التي وضعت من أجلها، لاحظ الباحث إن المقياس ملائم لتطبيقه على ولى طلبة الجامعة، بعد إجر اء بعض التعديلات اللغوية البسيطة لبعض الفقر ات حسب آلئ آراء المحكمين. ـ ثبات المقياس: استخرج الثبات الخاص بمقياس دافعية التعلم بالطر ائق الثناث :

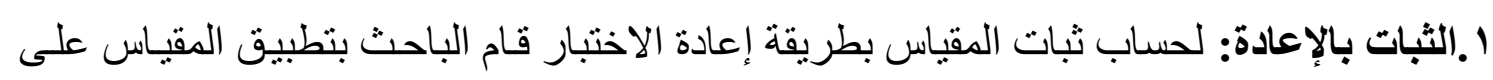

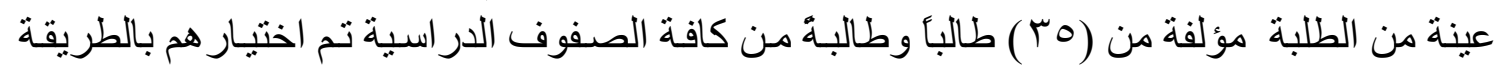

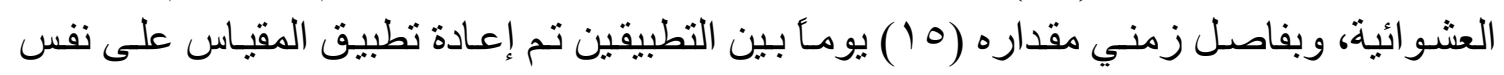
العينة، وحسب معامل ارتباط بيرسون بين وبفئ درجات التطبيقين. ץ. ثبات التجزئة النصفية: تم حساب معامل ثبات التجزئة النصفية من العينـة نفسها ومن التطبيق

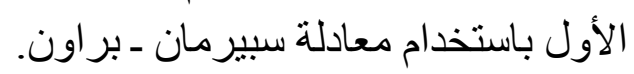

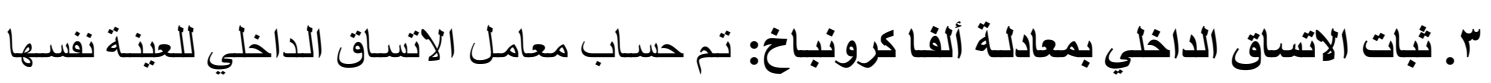

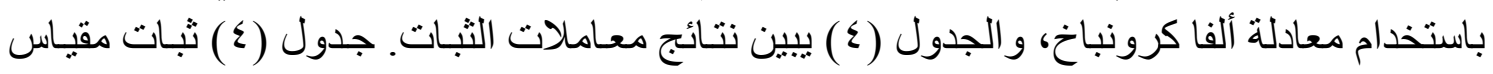

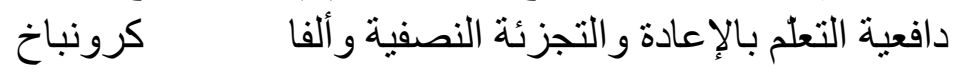

\begin{tabular}{|c|c|c|c|}
\hline ألفا كرونباخ & التجزئة النصفية & الثبات بالإعادة & مقياس استراتيجيات \\
\hline..$\wedge 7 * *$ & $\because V \nabla * *$ &.$\wedge r * *$ & \\
\hline
\end{tabular}
(**)

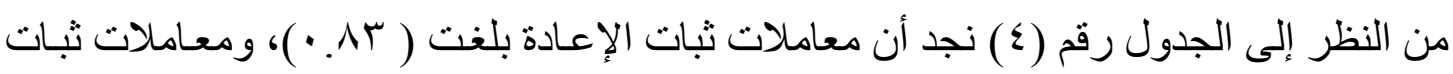

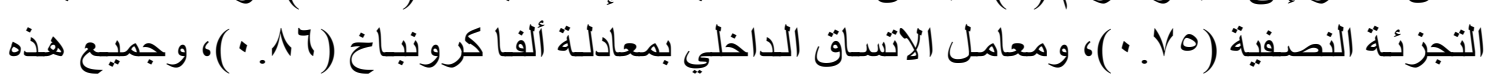

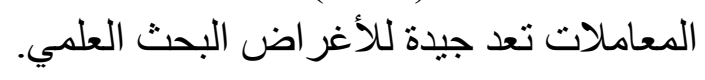

ويتضح من خلال حساب صدق وثبات المقياس بأنه يتصف بدرجة جيدة من الصدق و الثبات، مما

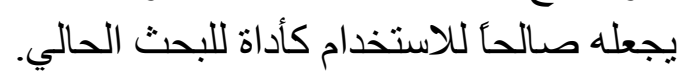

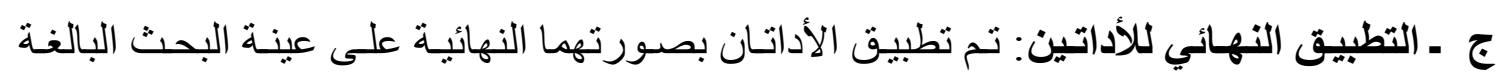

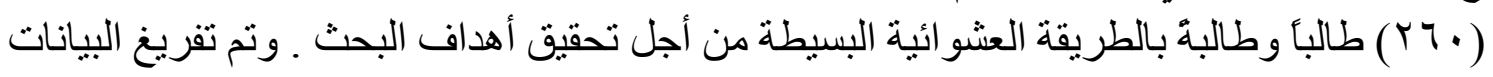

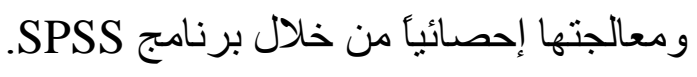

\section{ـ عرض نتائج البحث وتفسيرها:}

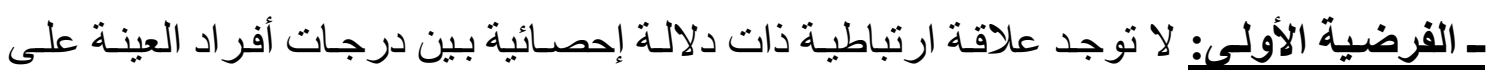

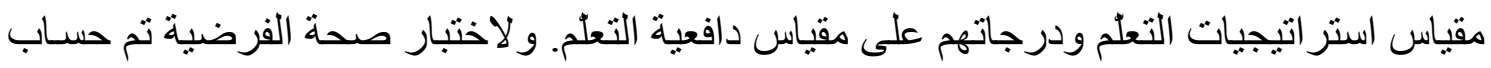

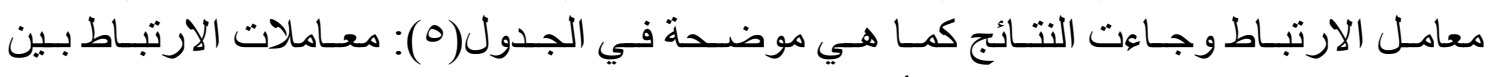
استر اتيجيات التعلم ودافعية التعلم لدى أفر اد عينة البحث دون 


\begin{tabular}{|c|c|c|c|c|c|c|c|}
\hline المجموع & الاختبّار & فعي التعلم الذات & معتقات & قالمهمة & اللخارجي & اللاخلي & \\
\hline. $.879 * *$ & $\begin{array}{l}-* * \\
-.194\end{array}$ &.$r V V * *$ & $\because Y .9 * *$ & $\because\{1 \wedge * *$ &.$\curlyvee q 9 * *$ &.$r \vee \wedge * *$ & التكرار \\
\hline.$\leqslant 7 \vee * *$ & $\because \wedge \theta_{-}$ & $\because \leqslant Y \leqslant * *$ & $.1 \leqslant r * *$ & $\cdot$ •r & . $r r q * *$ & $. r q \leqslant * *$ & الإتقان \\
\hline$. r \leqslant \Lambda * *$ & $\because 0 \varepsilon_{-}$ &.$r \Delta q * *$ & $\cdot .1 \cdot 1$ & $\cdot . r 10 * *$ & .YYl** & $\cdot . Y q 1 * *$ & التنظيم \\
\hline 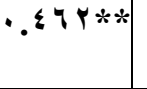 & $\begin{array}{l}-* * \\
\ddots r r r\end{array}$ & $\cdot r \Delta \wedge * *$ & $\because 1 \wedge r * *$ & $\because \leqslant Y \leqslant * *$ & $\cdot r \leqslant \Lambda * *$ & $\because\{9 \vee * *$ & التنفير \\
\hline $.7 r 9 * *$ & .119 & $\bullet \Delta Y \Delta * *$ & . Yฯ7** & . Orr** & $\because\{Y 0 * *$ & $\because$ Or $1 * *$ & التنظيم \\
\hline.$\sigma^{\top \wedge \mu * *}$ & $-\cdot . \cdot 1 \leqslant$ & •rrq** & .11. & $\cdot . r 4 \Lambda * *$ &.$r \ldots * *$ & . rrq** & إلدارة وقةت \\
\hline$\because r r r * *$ & $\because \wedge \varepsilon$ & $\because r \vee 0 * *$ & $\because \cdot 14$ & $\because Y \wedge V * *$ & $.171 \% *$ & $\cdot .11 \cdot * *$ & تنظيم الجها \\
\hline$\because r \wedge \Delta * *$ & $\because 991$ & $\because r \wedge r * *$ & $\because 9$. & $\because Y r \cdot * *$ & OYYY** & $.19 V * *$ & تعلم الرفاق \\
\hline. $.779 * *$ & $\because \cdot Y V$ & $.19 \leq * *$ & $\because$ Vo & $\because 177 * *$ & $\because Y \leqslant Y * *$ & DYYY** & البحثاعدة عن \\
\hline $.7 r \Lambda * *$ & $.11 \varepsilon_{-}$ & $\cdot 0 \leqslant \mu * *$ & $\because Y \backslash V * *$ & $\because \Delta r \leqslant * *$ & $\cdot . \leqslant \leqslant \mu * *$ & $.01, * *$ & المجموع \\
\hline
\end{tabular}

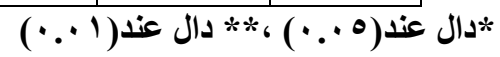

يتضح من الجدول ( 0 ) ما يلي :

- وجود ارتباط موجب (علاقة موجبة ) دال إحصائياً عند (1 · . · ) بين استر اتيجيات التعلم ودافعية

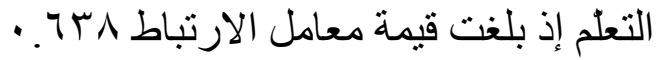

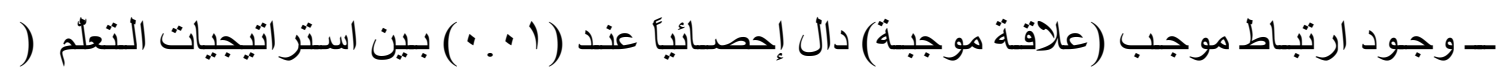

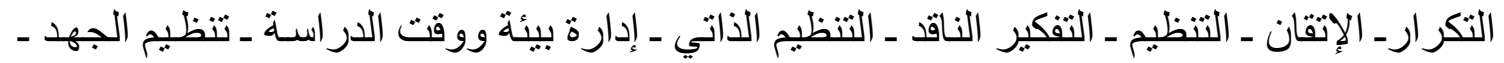

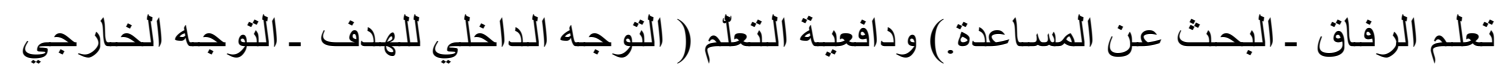

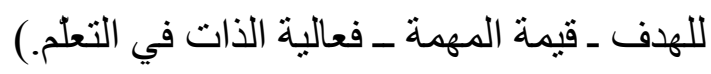

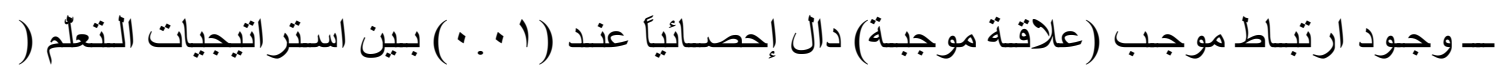

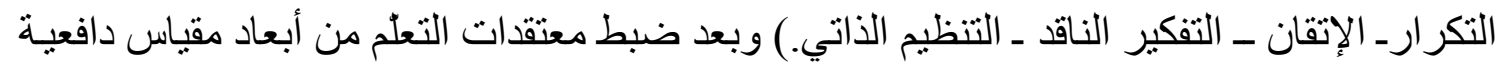

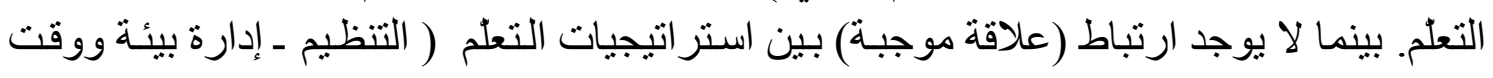
الدر اسة ـ تنظيم الجهد ـ تعلم الرفاق ـ البحث عن المساعدة )، وبعد ضبط معتقدات التعلم مـن أبعاد

المقياس

ـ وجود ارتباط سالب (علاقة سالبة) دال إحصائيً عند (1 . · ) بين استر اتيجيات التعلم ( التكرارالتفكير الناقد)، وبُعد قلق الإختبار.

تشير النتائج إلى وجود ارتباط موجب ودال إحصائيا بين استر اتيجيات التعلم ومعظم أبعاد مقياس

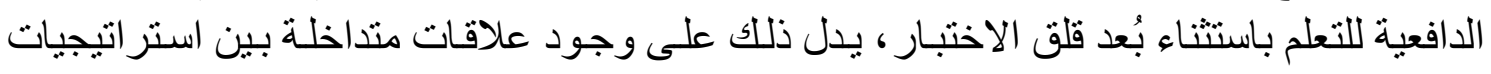
التعلم و الدافعية للتعلم لاى أفر اد عينة البحث من طلبة معلم الصف في في كلية التربية الثالثة. 
و عمومأ يمكن القول إن نتائج الدارسة الحالية تتفق مع نتائج الدر اسات السابقة ومن هذه الدر اسات

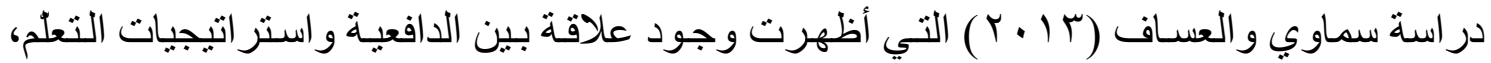

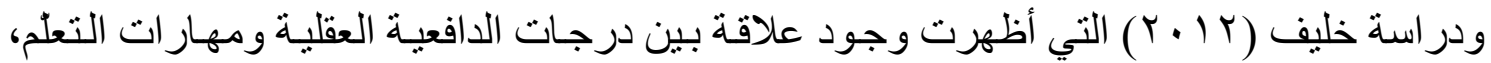

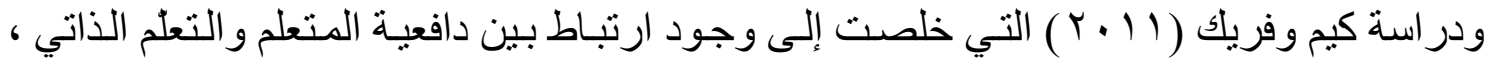

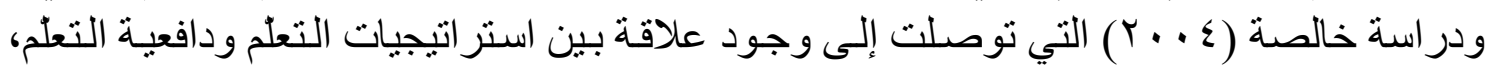

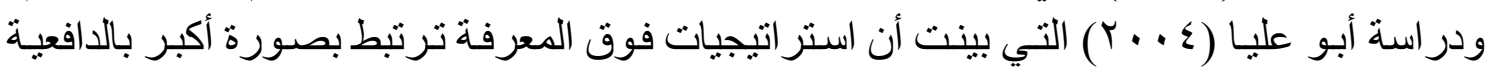
الداخلية عند طلبة الجامعة. وتعد هذه النتيجة منطقيـة باعتبـار أن التعلم يكون أكثر فاعليـة و وإتقانـا

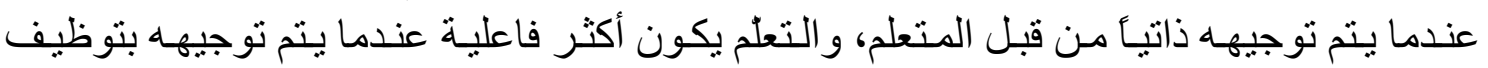
استر اتيجيات و اضحة من قبل المتعلم.

وقد يعزى ارتباط استر اتيجيات التعلم بمعظم أبعاد مقياس الدافعيـة للتعلم إلى أن الطلبـة يمتلكون

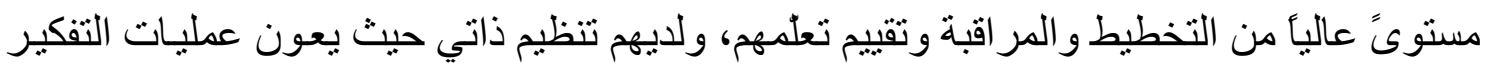
التي تحدث في التعلم و أنهم أكثر قدرة على تكييف استر اتيجياتهم للمهمـات الأكاديمية المتعددة.

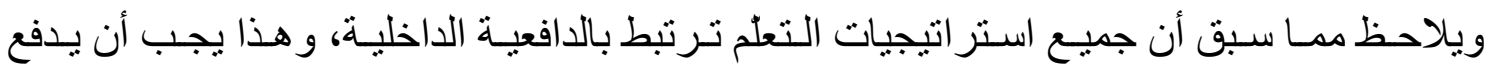

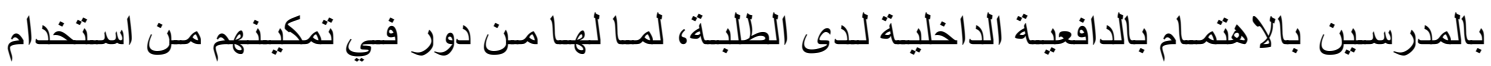
استر اتيجيات مختلفة تعكس اهتمام الطلاب بالمادة الدر اسية ومدى فهمها، وتحفيز الذات على التعلم و الوعي بالاستر اتيجيات التي يستخدمونها، والتركيز على المعنى و أهمية المعلومات الجديدة، إذ أكد سكنر (Skinner, et al.,1990) أن المعلمين يستطيعون تقوية الدافعية الداخلية لدى المتعلمين من ون خلال جعلهم يشعرون بأنهم مسيطرون ومسؤولون عن تعلمهم، ومديح المعلمين يساعد على تطوير كفايتهم الذاتية ويزيد من مستوى الدافعية الداخلية لديهم.

وما يدعم هذه النتيجة ملاحظات الباحث حيث أن معظم طلبـة كلية التربيـة الثالثة لديهم الدافعيـة

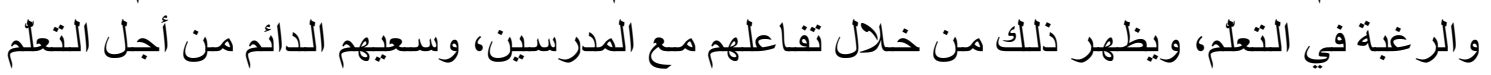

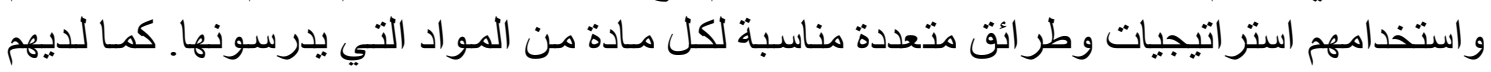

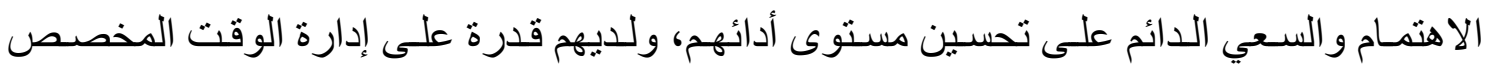

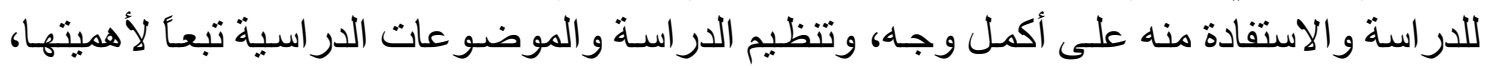
ولديهم القدرة على تنظيم جهودهم المبذولة في الدراسة، والرة الرغبة ونية في التفوق.

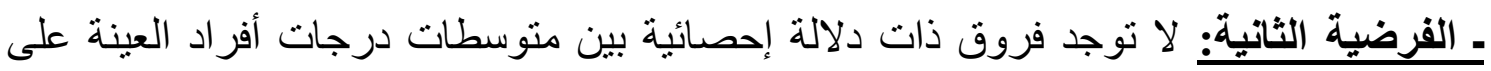
مقياسي استر اتيجيات التعلم ودافعية التعلم تعزى إلى متغير السنة الدر اسية (أولى ـ ثانية ــ الثالثةة). وللتحقق من صحة هذه الفرضية قام الباحث باستخدام اختبار تحليل التباين الأحادي، وجاءت التئ النتائج كما بلي: 
جدول (T) تحليل التباين الأحادي للفروق بين متوسطات درجات أفر اد العينة على مقياسي

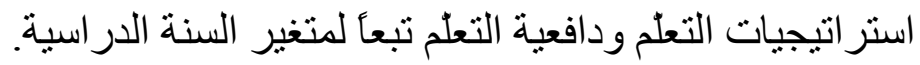

\begin{tabular}{|c|c|c|c|c|c|c|}
\hline مستوى & "فيمة" & متوسط المربعات & ح.د & مجموع المربعات & مصادر التباين & المتغيرات \\
\hline$* . . r_{1}$ & 4.019 & $\begin{array}{l}\leqslant 7 V 0 . \leqslant 79 \\
\text { IrYA.VTA }\end{array}$ & $\begin{array}{r}\text { rov } \\
\text { rov }\end{array}$ & $\begin{array}{c}9 r 0 . .9 r V \\
r \leq 1 \leq 10.091\end{array}$ & داخل المجموعات المجموعات & استراتيجيات \\
\hline$\because \leqslant 0 \wedge$ & $\because \vee \wedge r$ & 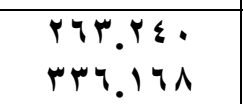 & $\begin{array}{c}r \\
r \circ v\end{array}$ & 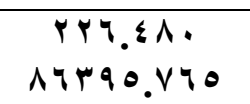 & داخل المجموعات & دافعية التعلم \\
\hline
\end{tabular}

* دال عند مستوى (ه . . ) واتجاه الفروق لصالح السنة الأولى وفق اختبار شيفيه

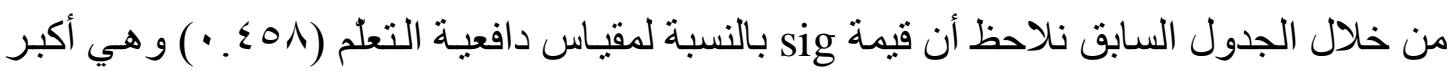

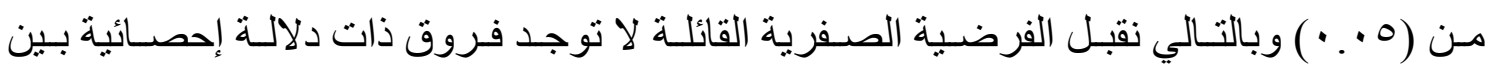

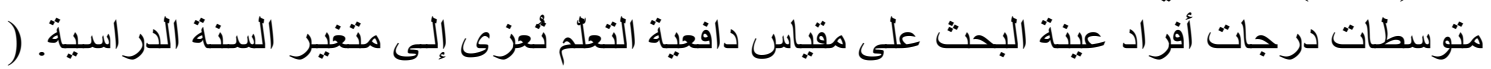
أولى ـ ثنانية ـ الثالثة ).

و مـن خـلال الجدول السـابق نلاحظ أن قيمـة sig بالنسبة لمقيـاس استر اتيجيات التعلم ( اس •. • ) و هي أصغر من (0 . . •) وبالتـالي نرفض الفرضية الصفرية ونقبل الفرضية البديلة لها و القائلة

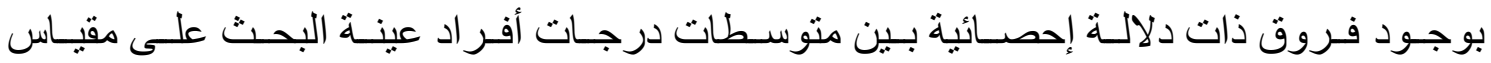

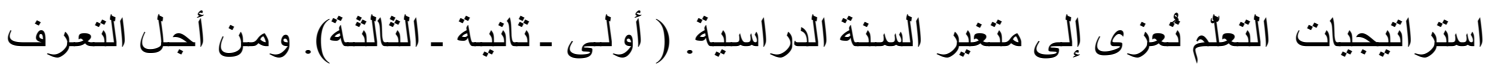
إلى مقدار هذه الفروق بين المتوسطات ومستوى دلالتها والمجمو عات التي تظهر فيها هذه الفروق.

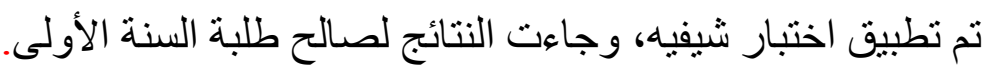

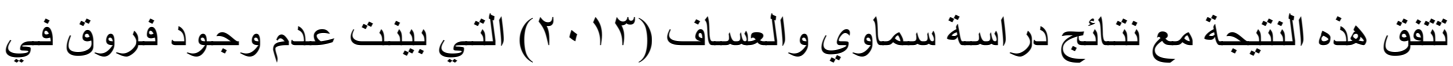

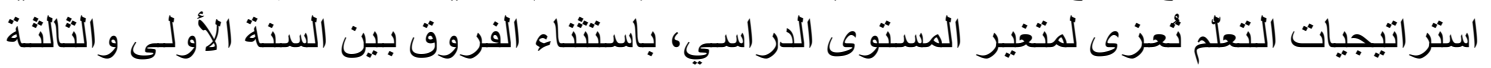

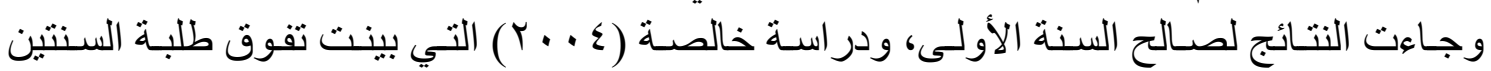

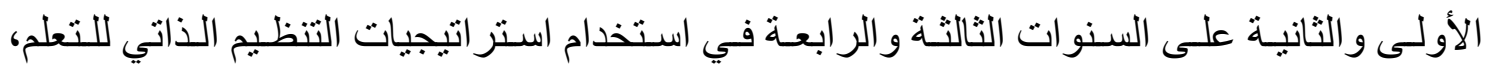

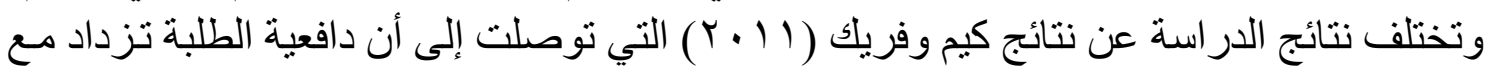

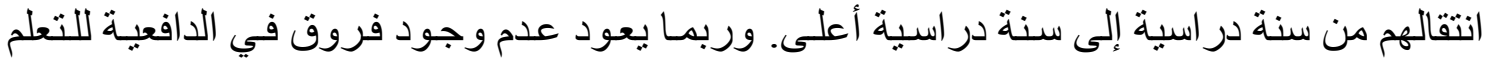

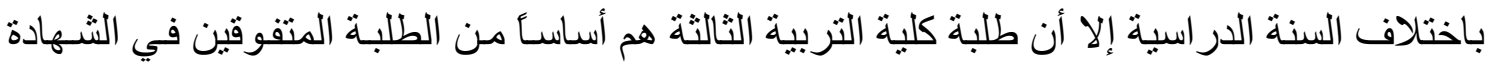

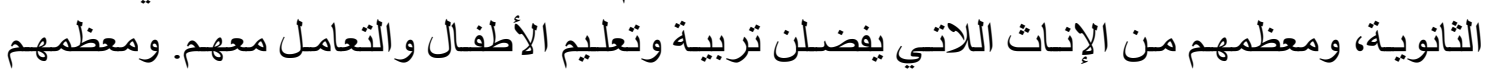
اختاروا الدر اسة في قسم معلم الصف منذ البداية عن قناعة ور غبة، وتوجد لديهم دافعية و واتجاهـات ايجابية مسبقة نحو در اسة معلم الصف كل ذلك انعكس إيجابً على دافعية التعلم لدى جميع الطلاب .

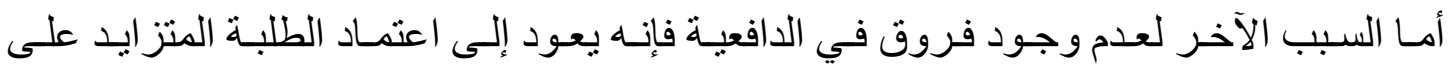

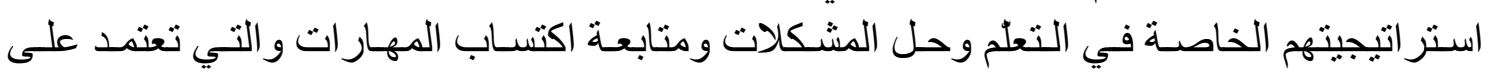
الخبرات التي تكونت لديهم في السنة الأولى. 
ويرى الباحث أن الفروق في استر اتيجيات التعلم بين طلبـة السنة الأولى و الثالثـة لصـالح طلبـة

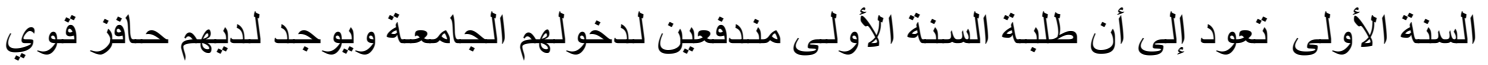

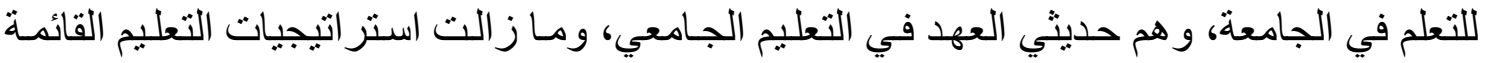

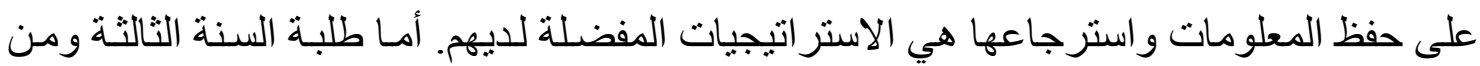

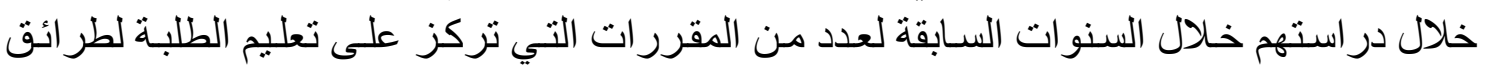
و أساليب التعلم المناسبة لخصائص كل مقرر من المقررات طوروا من استر اتيجيات التعلم للديهم،

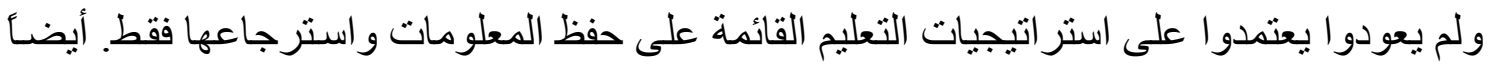

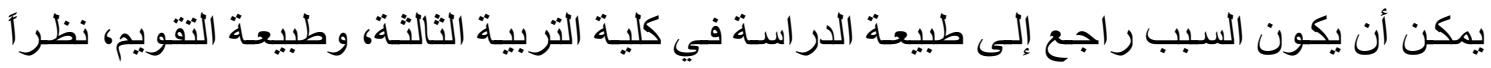

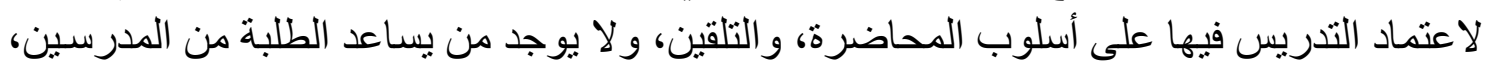

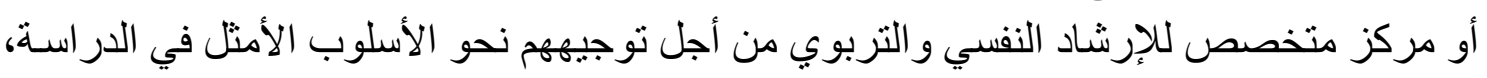
فالتحصيل الدر اسي بوصفه نتاجأ للبنية المعرفية يرتبط بكل من طبيعة تكوين هذه البنية، و أسلوب التب تنظيمها، وتنظيم بيئة التعلم و التقويم الذاتي.

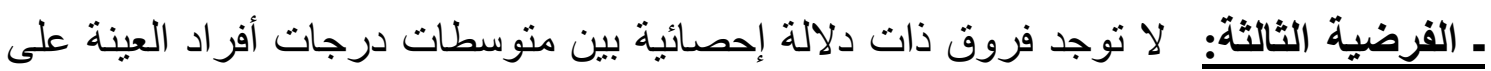
مقياسي استر اتيجيات التعلم ودافعية التعلم تعزى إلى متغير نوع الثهادة الثانوية (علمي ـ أدبي). وللتحقق من صحة هذه الفرضية قام الباحث بحساب الفروق بين متوسطات درجات أفراد عينة

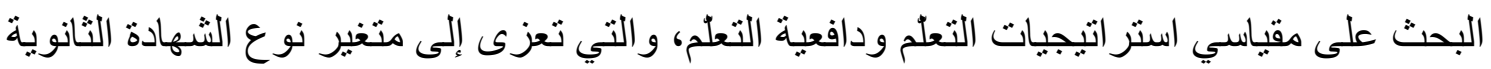

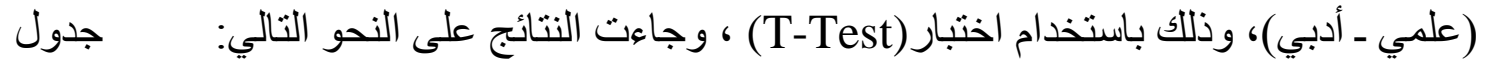
اختبار(T-Test (V)

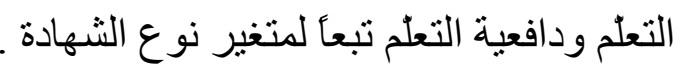

\begin{tabular}{|c|c|c|c|c|c|c|c|}
\hline القرار & 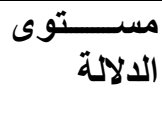 & قيمت (ت) & المعياريــــــ & الحستوبي & العدد & 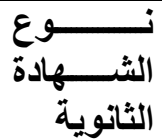 & \\
\hline \multirow[t]{2}{*}{ غير دال } & \multirow[t]{2}{*}{.01.} & \multirow[t]{2}{*}{.97.} & TV.Yo & $r V I . \cdot r$ & 171 & أدبي & \multirow{2}{*}{ التعلم اتيجيات } \\
\hline & & & ro.rT & YTV.9Y & 99 & علمى & \\
\hline \multirow[t]{2}{*}{ غير دال } & \multirow[t]{2}{*}{$\cdot \Delta 1 T$} & \multirow[t]{2}{*}{$\because Y M V$} & 11.40 & $10 \cdot .71$ & 171 & أدبي & \multirow[t]{2}{*}{ الدافعية للتعلم } \\
\hline & & & 11.01 & $101 . \mathrm{rr}$ & 99 & علمى & \\
\hline
\end{tabular}

مـن خـلال الجدول السـابق نلاحظظ أن قيمـة sig ( • (0. • ) بالنسـبة لمقيـاس اسـتر اتيجيات التعلّم

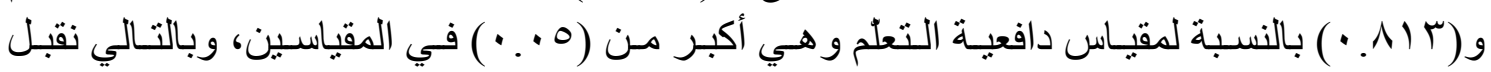

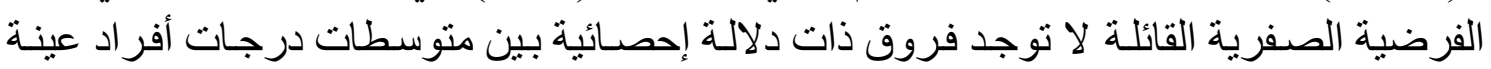

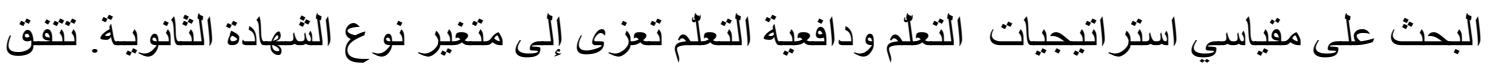

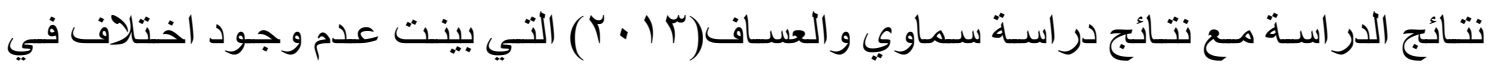

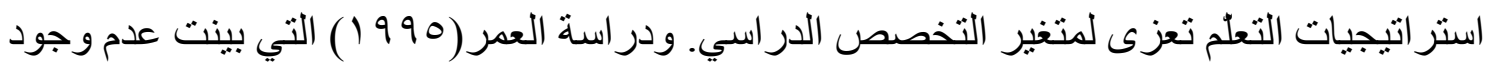

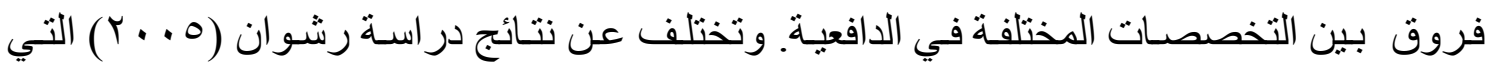

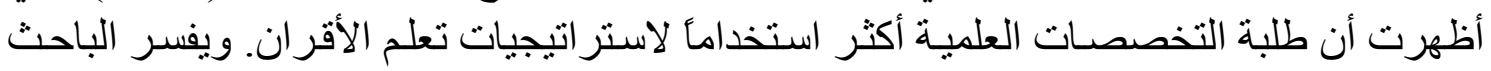
هذه النتيجة بأن طلبة الثهادة الثانوية بفر عيها العلمي و الأدبـي بعد دخولهم إلى كليـة التربيـة الثالثة 
قسـم معلـم الصـــ تلقـو ا نفس المعلومـات، واسـتخدم معهم المدرسـين نفس الطر ائقق والأسـاليب

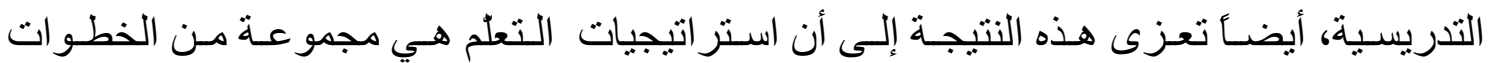

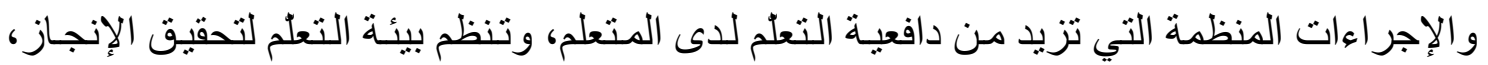

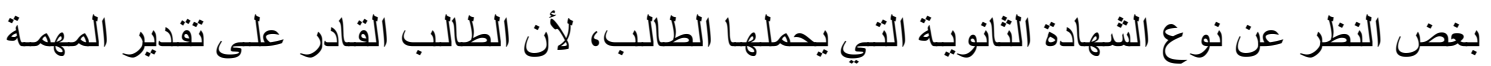

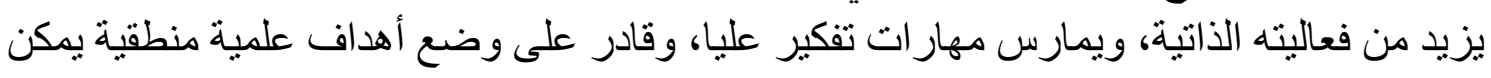
تحقيقها بشكل منطقي منظم.

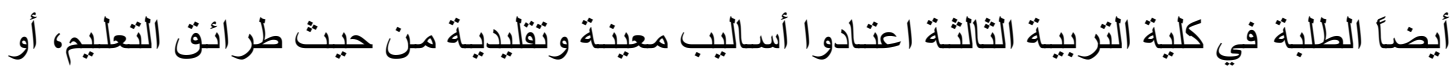

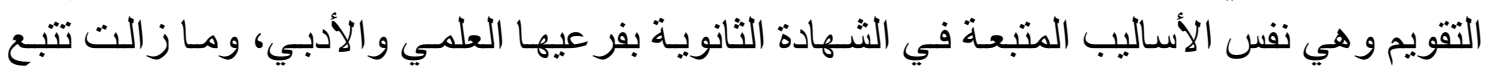
استر اتيجيات تعلم تقليدية قائمة على التلقين الحرفي و الحفظ الحرفي الصم في الثـهادة الثانويـة وفي وفي

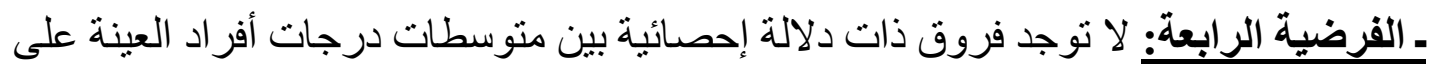

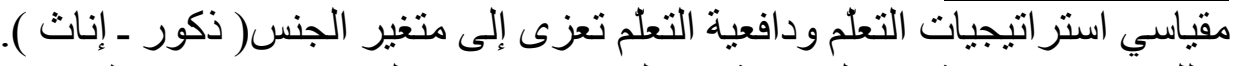

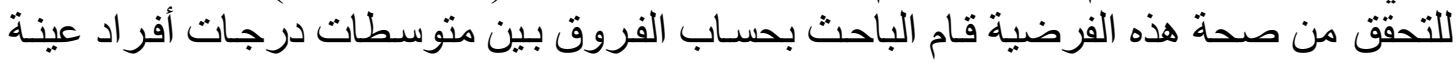

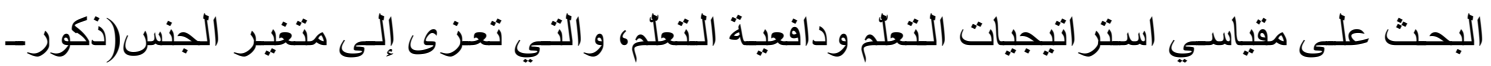

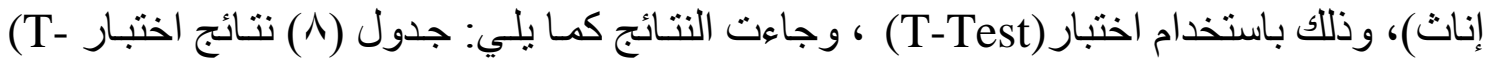
Test) التعلم تبعأ لمتغير الجنس(ذكور - إناث).

\begin{tabular}{|c|c|c|c|c|c|c|c|}
\hline القزار & الدلالة مستوى & قيمت (ت) & المعياريـــــــ اف & الحستوسي & العدد & الجنس & \\
\hline \multirow[t]{2}{*}{ غير دال } & \multirow[t]{2}{*}{. .94} & \multirow[t]{2}{*}{1.711} & ro.771 & rVI.90 & r.. & إناث & \multirow{2}{*}{ استراتيجيات } \\
\hline & & & rq.q. & YTY.AT & 7. & ذكور & \\
\hline \multirow[t]{2}{*}{ غير دال } & \multirow[t]{2}{*}{.$r Y V$} & \multirow[t]{2}{*}{$\because 9 \wedge r$} & TV.TY & 101.00 & $r \ldots$ & إناث & \multirow[t]{2}{*}{ دافعية التعلّم } \\
\hline & & & $r \cdot . \leqslant q$ & $1 \leqslant \Lambda_{0} \wedge \theta$ & 7. & ذكور & \\
\hline
\end{tabular}

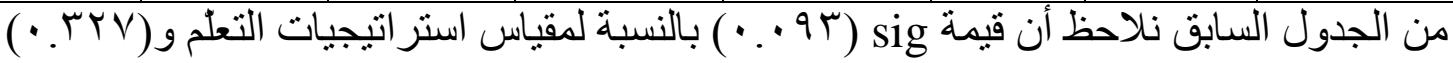
بالنسبة لمقياس دافعية التعلم و هي أكبر دن (0 . . ) في المقياسين، وبالتالي نقبل الفرضية الصفرية

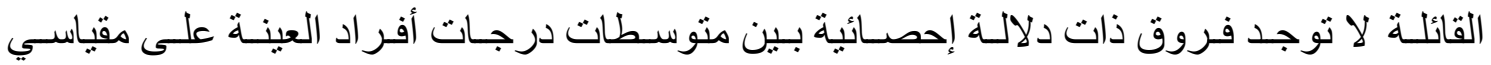
استر اتيجيات التعلم ودافعية التعلم تعزى إلى متغير الجنس.

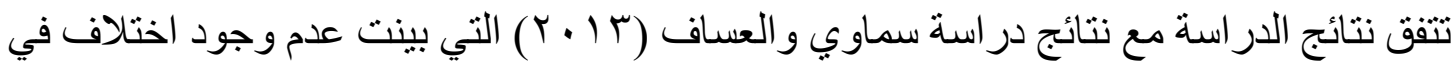

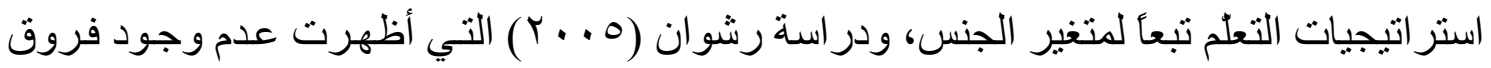

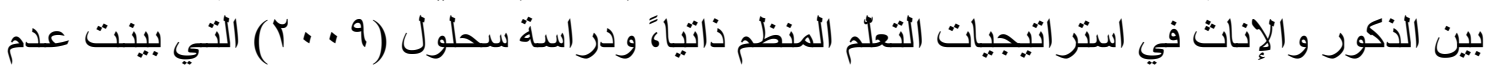

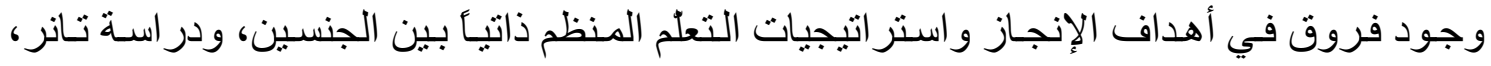

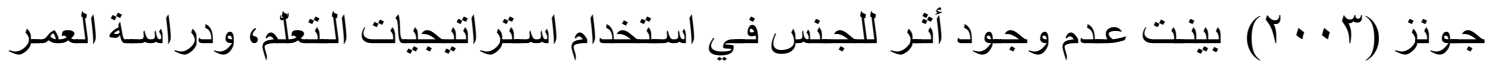

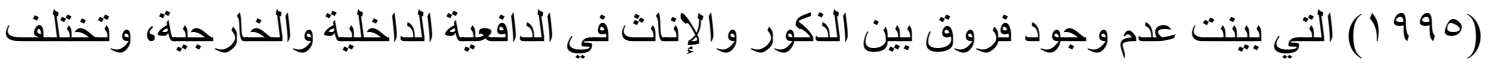




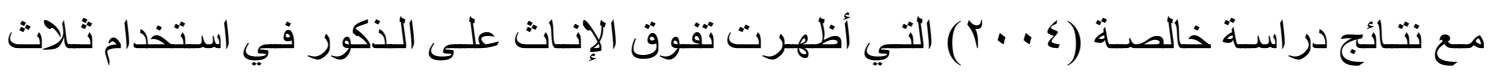
استر اتيجيات من استر اتيجيات التعلم.

ويفسر الباحث هذه النتيجة بأن الدافعية للتعلم متقاربة لدى طلبة كلية التربية الثالثة بغض النظر التبر

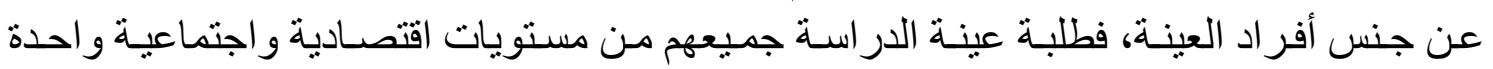

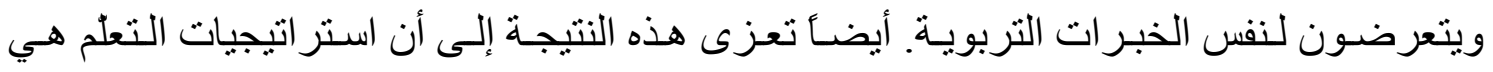

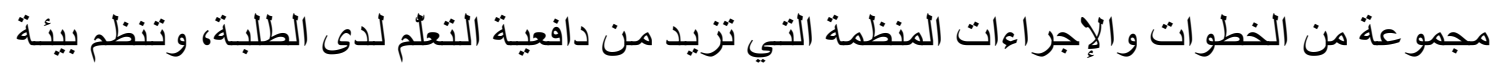
التعلم لتحقيق الإنجاز ، بغض النظر عن جنس الطالب، لأن الطالب القادر على تقدير المهيـة يزيد

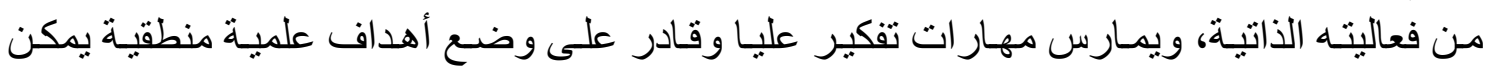
تحقيقها بشكل منطقي منظم. فئه النة وينار

ويمكن أن تعود هذه النتيجـة إلى أن الذكور و الإنـاث في كليـة التربيـة الثالثة بدرسون المقررات

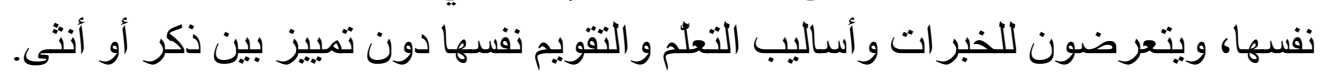

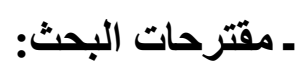

في ضو ء نتائج الدر اسة يمكن تقديم المقترحات التالية:

ـ إجراء المزيد من الدراسات لدر اسة العلاقة بين استر اتيجيات التعلم والدافعية للتعلم لدى عينات أخرى وكليات ذات تخصصات علمية و أدبية.

ـ العمل علي تطوير برامج إعداد المعلمين وتنفيذ دورات وورش عمل للمعلمين أثناء الخدمة لتمكينهم من اكتساب استر اتيجيات التعلم الفعالة.

ـ العمل علي تجاوز الأساليب التقليدية في التعليم الجامعي وتدريب الطلبة علي ممارسة

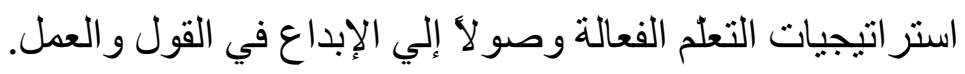

ـ توجيه المعنيين بإرشاد الطلبة إلى بناء البرامج التدرييية لتعزيز دافعية الطلبة للتعلم.

ـ إجراء دراسات مقارنة لتحديد الأفضل والأكثر فاعلية بين بعض الاستراتيجيات والأساليب المستخدمة لتتمية مهار ات تدريس معلمي ومعلمات الحلقة الأولى من مرحلة التعليم الأساسي. 


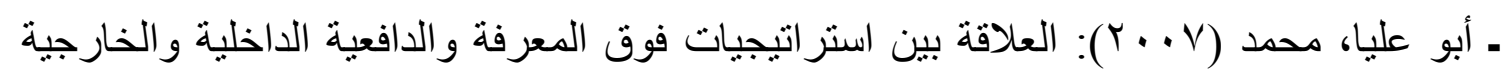

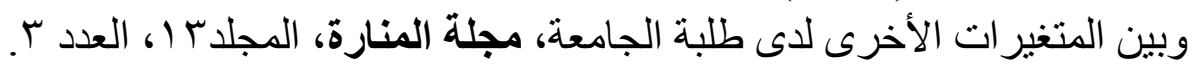

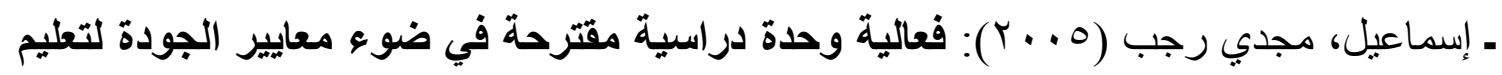

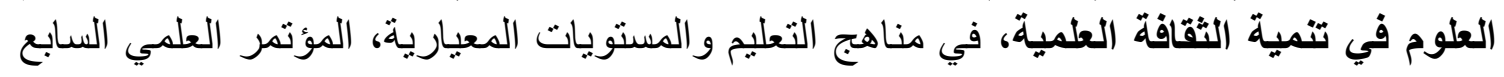

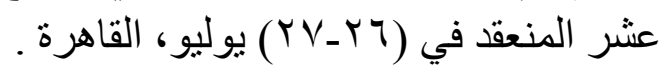

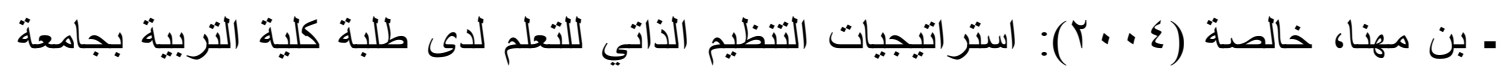

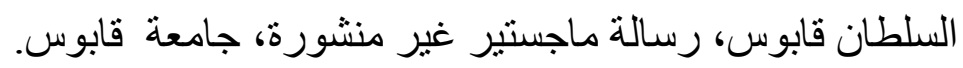

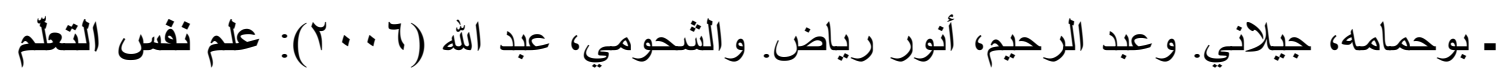
والتعليم، الأهلية للنشر و التوزيع، الكويت.

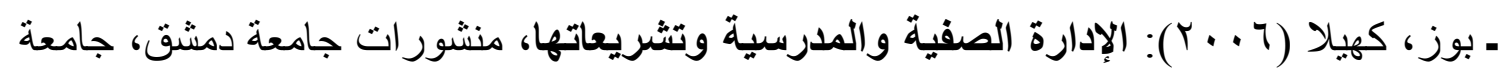
دمشق.

- جابر عبد الحميد، جابر (999(1)): استراتيجيات التدريس والتقلم، سلسلة كتاب علم النفس و التربية، الكتاب العاثر، دارير الفكر العربي، القاهرة.

ـ الحيلة، محمد محمود ( ץ . . Y): مهارات التدريس الصفي، دار المسيرة، عمّان.

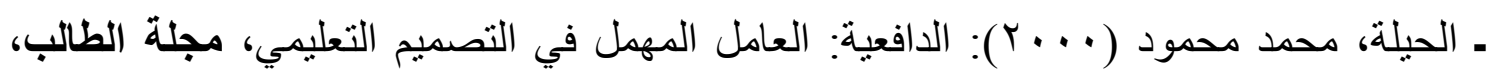

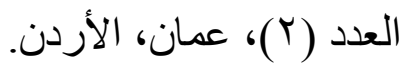

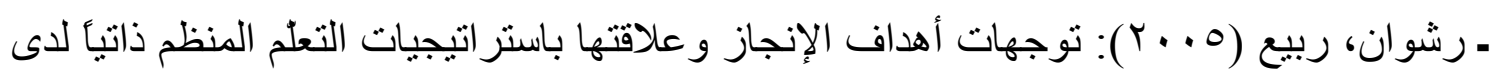

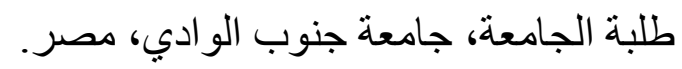

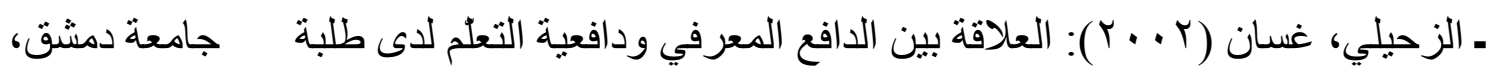

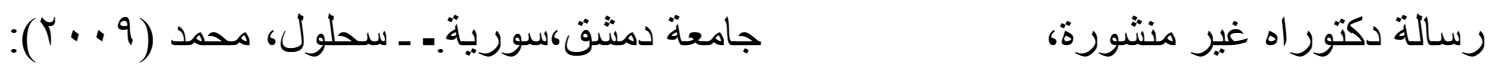

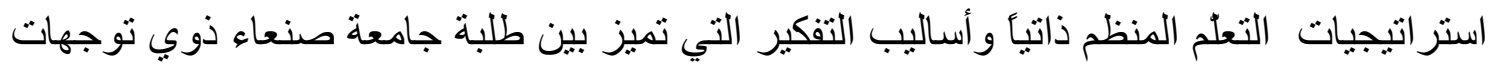

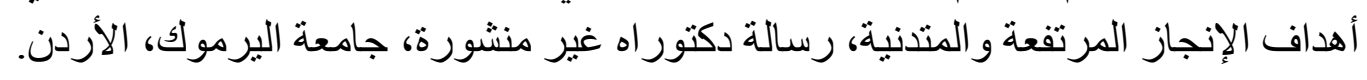

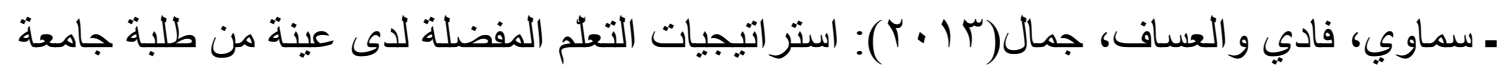

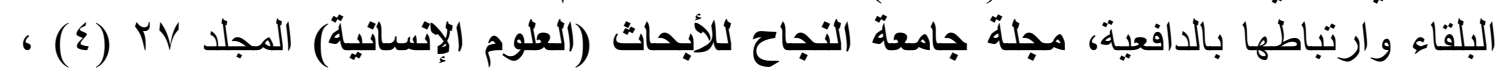
r. r

ـ شحاتة، حسن(7 + . ץ): التعلم دعوة للحوار في الوطن العربي، الدار المصرية اللبنانية.

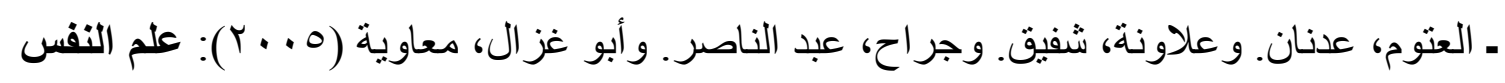


التربوي النظرية والتطبيق، دار المسيرة، عمان.

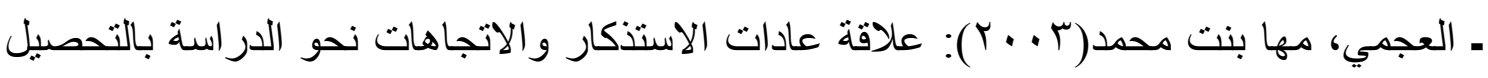

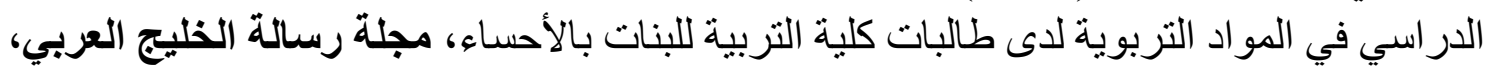

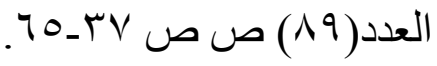

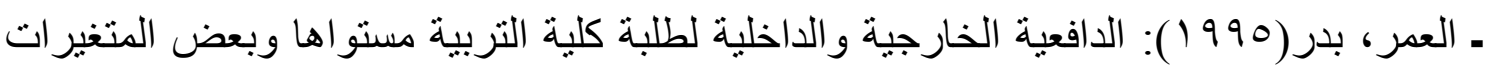

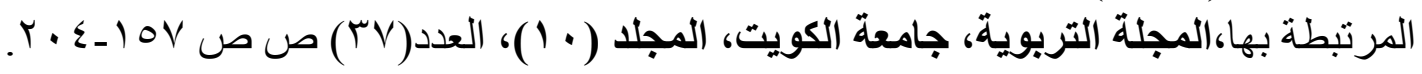

ـ قطامي، يوسف وأبو جابر، ماجد وقطامي، نايفه (.... †): تصميم التدريس، الطبعة الأولى، دار

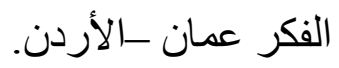

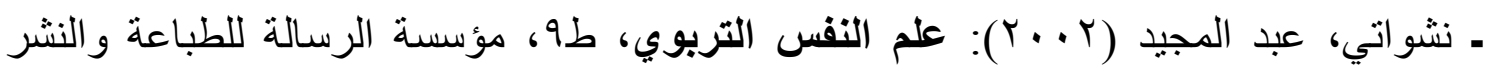
و التوزيع، بيروت، لبنو لبنان.

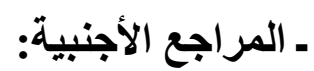

- Gottfried, A. (1994): Role of parental motivational practices on children's academic intrinsic motivation and achievement, journal of Educational psychology, V (5) , 15- 29.

- Hartnett, M., St George, A., \& Dron, J. (2011). Being together-factors that unintentionally undermine motivation. Journal of Open, Flexible and Distance Learning, 15(1), 1-16.

- Kember, D. \& Pleung, D. (2003): The dimensionality of approaches to learning, British journal of Education psychology, Vol. (68) , 376 - 398. - Kollb , D (1984) . Experiential Learning Experience as The Source Of Learning and Development . London , Prentice - Hall International, Inc.

- Miller , P. (2001): Learning Styles: The Multimedia Of the Mind, the Mind, the Annual Meeting of the American Educational Research , San Diego , v4 , 115- 135.

- Pintrich, P. (2000). "Multiple Goals. Multiple Pathways: The Role Goals orientation in Learning and Achievement". Journal of Education Psychology. 92(3). 544-555.

- Pintrich, P. \& De Groot, E. (1990). "Motivational and Self-Regulated Learning components of classroom academic performance". Journal of Education Psychology. 82(1). 33-40

- Schunk, D. (1991). Self-efficacy and academic motivation Educational Applied Linguistics. 11(12). 129-158.

- Skinner, E. A., Welborn, J.G. \& Connell, J.P. (1990). What It Takes to do well in School and Whether I've Got It: A Process Model of Perceived 
Control and Children's Engagement and Achievement in School. Journal of Educational Psyohology, 82, 22 -32.

- Tanner, H \& Jones, S. (2003). "Self Efficacy in Mathematics and students use of self regulated learning strategies". The Psychology of mathematics education. 4(1). 275- 282.

- Wolters, C. \& Rosenthal, H. (2000): "The Relation between Students Motivational Beliefs and their Use of Motivational Regulation Strategies". International Journal of Educational Research. 1(33). 801-205.

- Zimmerman. (2000). Attaining Self- Regulation: Asocial cognitive perspective In M. Boekaerts. P. R. Pintrich. M.Zeidner (Eds.). Handbook of Self- Regulation (pp.13-39). California: Academic Press 


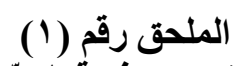

مقياس دافعية التعلّ

ا - (الرقم الجامعي ) :

rـ المستوى الدراسي :

ع ـ نوع الثهادة الثانوية ـ .

rـ الكلية :

عزيزتي الطالبة. عزيزي الطالب ..

العبار ات التالية تسأل عن دافعيتك للتعلم في هذا الفصل الدراسي، ولا توجد إجابة صحيحة وأخرى خاطئة لهذا

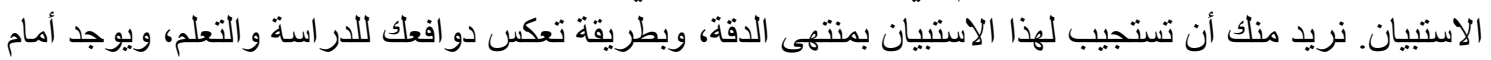

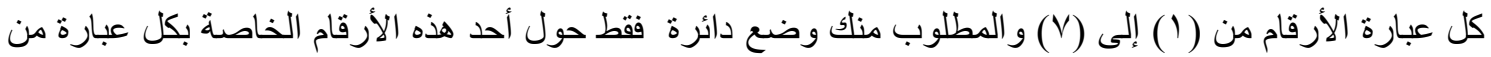

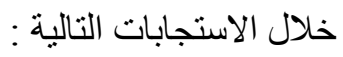

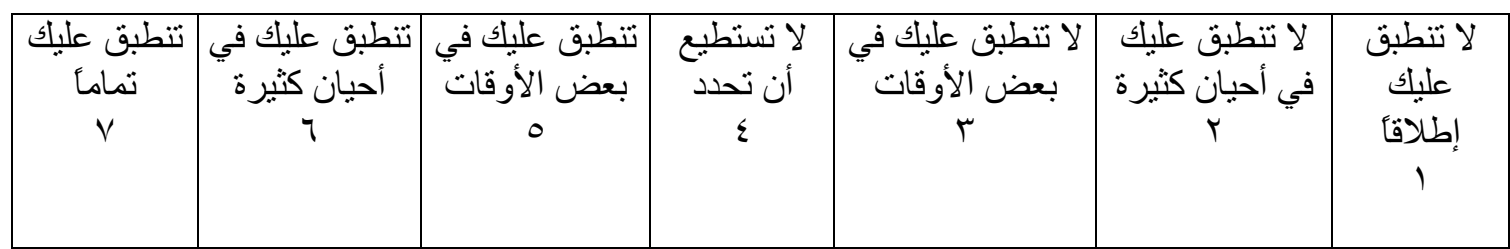

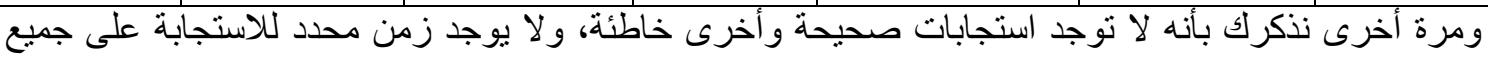

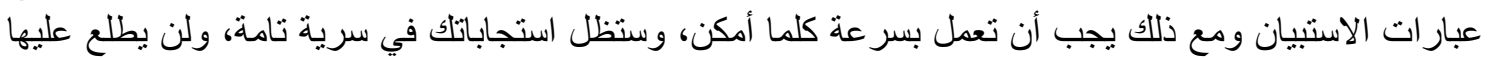
احد غير الباحث، ولن تستخدم إلا في أغر اض البحث العلى بـر العي. وشكراً لتعاونكم

\begin{tabular}{|c|c|c|c|c|c|c|c|}
\hline $\mathrm{V}$ & 7 & 0 & $\varepsilon$ & r & 1 & 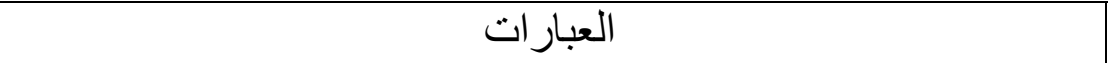 & ? \\
\hline & & & & & & أفضل المو اد الدر اسية التي تتحداني ولذلك أستطيع تعلم أشياء جديدة. & 1 \\
\hline & & & & & & إذا درست الفصل. بطرق مناسبة عندئذٍ سأكون قادراً على تعلم المواد الدر اسية في & r \\
\hline & & & & & & الآخرين. & r \\
\hline & & & & & & 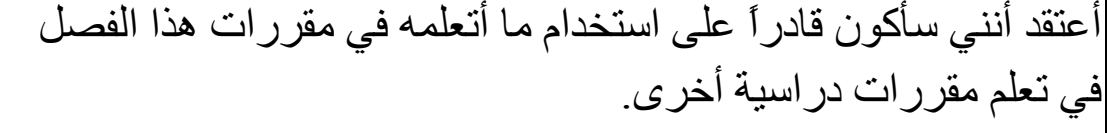 & 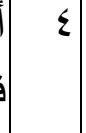 \\
\hline & & & & & & أعتقد أنني سأحصل على درجات ممتازة في هذا الفصل الدر اسي. & 0 \\
\hline & & & & & & المقرر ات المخصد مقدرتي على فهم معظم المعلو مات الفصل الدراسي. & 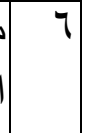 \\
\hline & & & & & & الحصول على درجات جيدة في هذا الفصل الدر اسي هو الثيء الذي & V \\
\hline
\end{tabular}




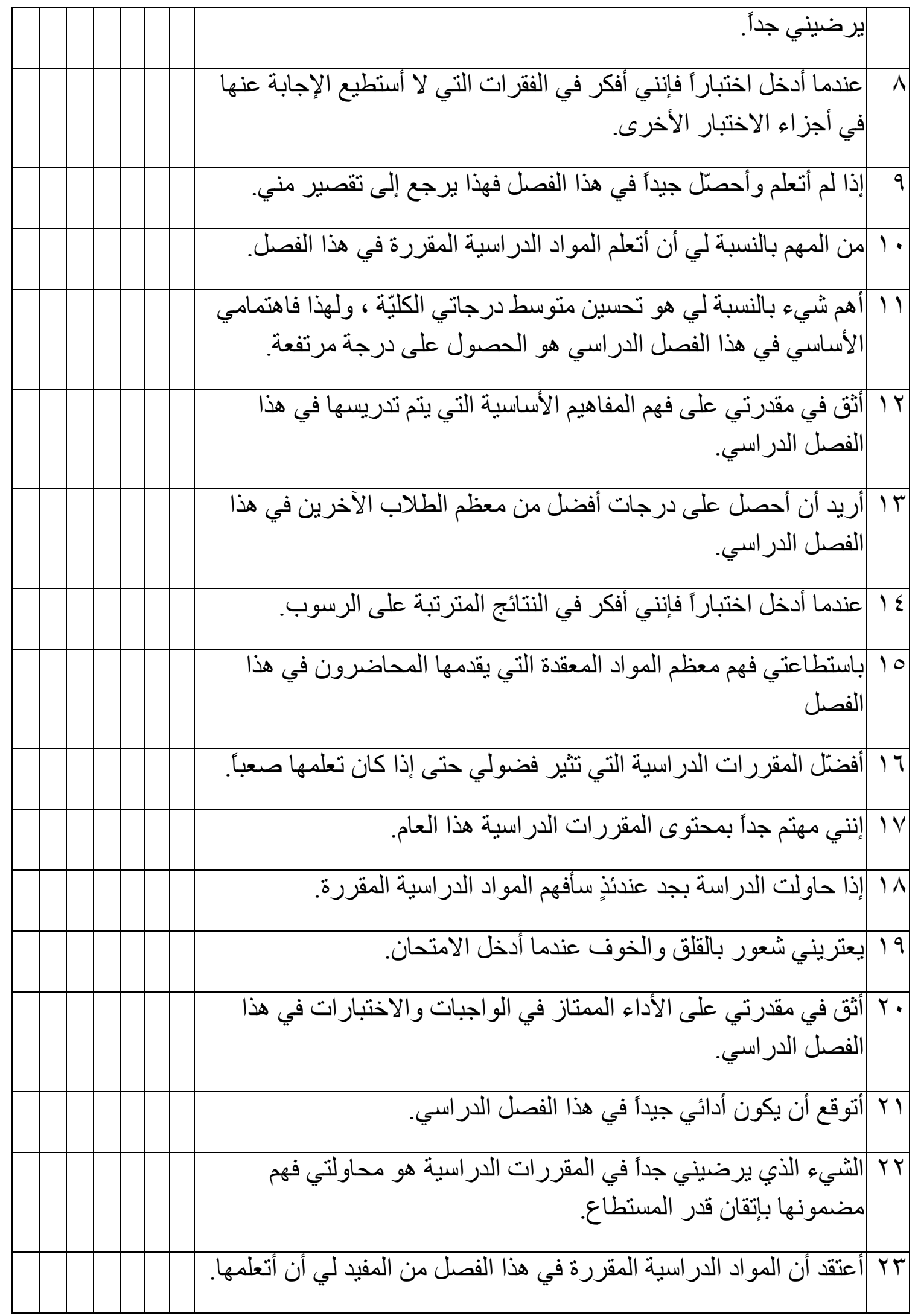




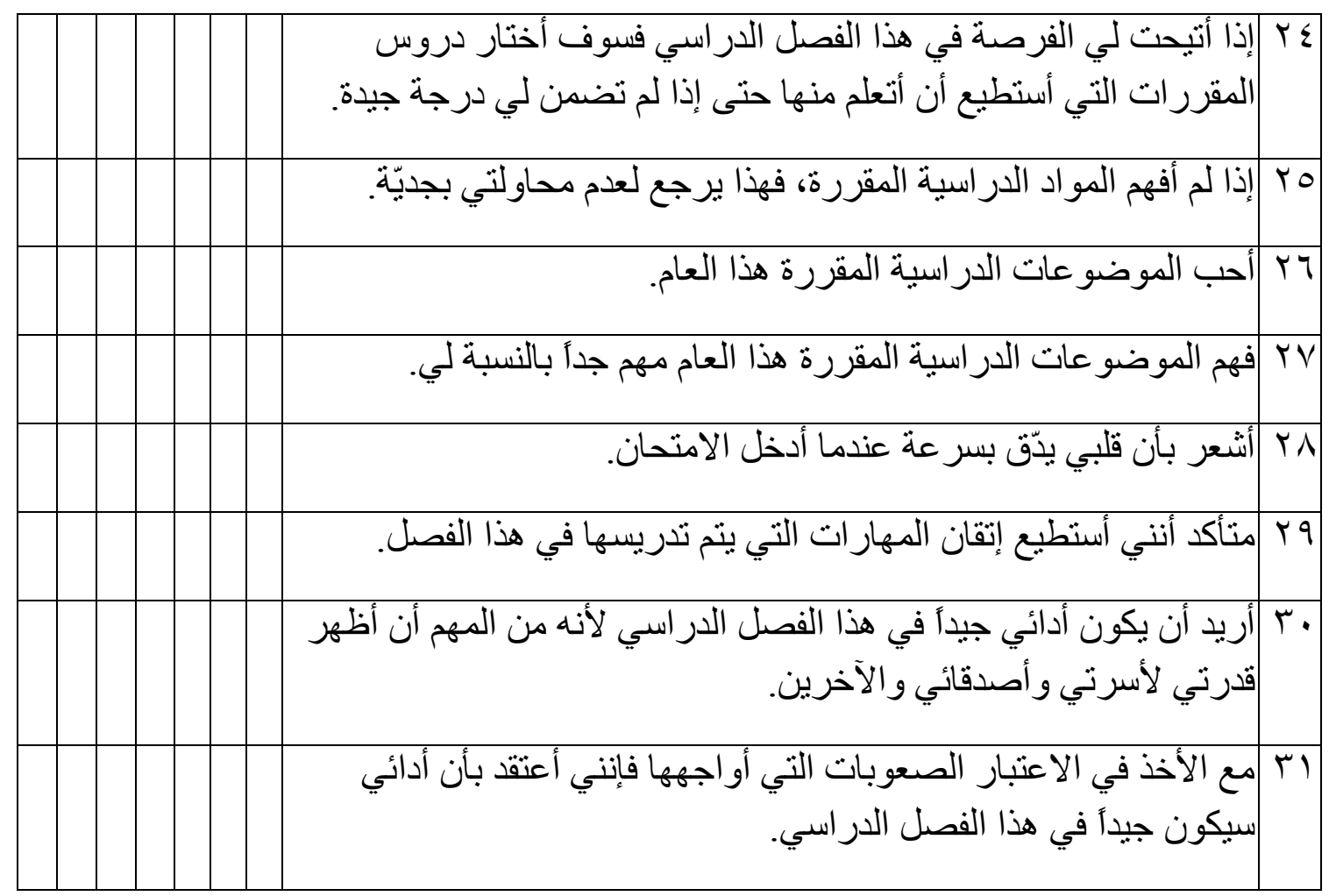


The relationship between learning strategies and Motivation at third college education students in albaath university

\author{
Ahmed Haj Mosse \\ Collage of Education-Albaath University
}

\begin{abstract}
This research aim to recognize relationship between learning strategies and Motivation at third college education students, and known differences of means on learning strategies and Motivation scales according to three type variable: sex, specific, and study years. To achieve this aims, the researcher used Pintrich's scale (1991) for measuring the learning strategies, Pintrich's scale (1991) for measuring the Motivation toward learning. The research sample consist of (260) student male and female in Albaath University.

This study get to the following results:

1-There were significant statistical Correlation at the 0.05 level of significance, Between the (learning strategies and Motivation)

2 - There were no significant statistical differences at the 0.05 level of significance among the study groups on Motivation scale according to study years variable.

3-There were no significant statistical differences at the 0.05 level of significance among the study groups on learning strategies and Motivation scales according to sex, and specific variables.

4- There were significant statistical differences at the 0.05 level of significance among the the study groups, according to study years variable, In favour of the year one students.
\end{abstract}

